\title{
Constitutional Representations of the Family in Public Schools: Ensuring Equal Protection for All Students Regardless of Parental Sexual Orientation or Gender Identity
}

\author{
AmANDA HARMON COOLEY* \\ "The desire of the legislature to foster a homogeneous people with \\ American ideals prepared readily to understand current discussions of \\ civic matters is easy to appreciate."'
}

\section{TABLE OF CONTENTS}

I. INTRODUCTION 1008

II. State Legislation That StigMatizes OR PROHiBits THE

TEACHING OF LGBTQI RELATIONSHIPS IN PUBLIC SCHOOLS ...1012

III. THE HARM ENGENDERED BY STATE LEGISLATION THAT Stigmatizes or Prohibits THE TEACHING OF LGBTQI RELATIONSHIPS IN PUBLIC SCHOOLS

IV. Student-Centered, Federal Constitutional Challenges to State Legislation That Stigmatizes OR PROHIBITS THE TEACHING OF LGBTQI RELATIONSHIPS In Public Schools: A Necessary Course of ACTION

A. The Lack of Alternative Options to Adequately

Remediate the Harm of State Legislation That

Stigmatizes or Prohibits the Teaching of LGBTQI

Relationships in Public Schools

B. The Viability of Student-Centered, Federal Constitutional

Lawsuits to Adequately Remediate the Harm of State

Legislation That Stigmatizes or Prohibits the Teaching

of LGBTQI Relationships in Public Schools.

V. CONCLUSION 1048

\footnotetext{
* Associate Professor of Law, South Texas College of Law. J.D., The University of North Carolina at Chapel Hill, 2003; B.A., The University of North Carolina at Chapel Hill, 2000. The author would like to thank South Texas College of Law for its research support and her colleagues at South Texas for their valuable feedback. An earlier draft of this paper was presented at the 2013 Southeastern Association of Law Schools Conference. The author expresses her sincere gratitude for all of the helpful feedback from this SEALS presentation.

${ }^{1}$ Meyer v. Nebraska, 262 U.S. 390, 402 (1923).
} 


\section{INTRODUCTION}

The development of a constitutional role for the family has been significant in demarcating the public and private spheres of life, along with setting limits on governmental control, in American jurisprudence. ${ }^{2}$ This assignment of constitutional import to the family has become especially significant in the context of education. ${ }^{3}$ Indeed, the seminal cases of Meyer $v$. Nebraska and Pierce v. Society of Sisters that established the constitutional status of the family involved this precise topic. ${ }^{4}$ These cases illustrate the inherent tension between the wishes of families with children and of the state educational institutions that are charged with acting in loco parentis for those children. ${ }^{5}$ Therefore, it should not be surprising that battles regarding the boundaries of state control over citizens and their families often involve education. ${ }^{6}$

A particularly controversial struggle involving education, family, and the Constitution is now being waged regarding state curricular laws that stigmatize or prohibit the teaching of lesbian, gay, bisexual, transgender, queer/questioning, or intersex (LGBTQI) relationships in public schools. ${ }^{7}$

${ }^{2}$ See Mark E. Brandon, Home on the Range: Family and Constitutionalism in American Continental Settlement, 52 EMORY L.J. 645, 647-48 (2003) (noting that repeated references to family by divergent Supreme Court justices throughout the twentieth century have resulted in "[f]amily . . . becom[ing] a basis for constitutional judgment").

${ }^{3}$ See Kay P. Kindred, God Bless the Child: Poor Children, Parens Patriae, and a State Obligation to Provide Assistance, 57 OHIO ST. L.J. 519, 525 (1996) (noting the constitutional protection allocated to "the establishment and maintenance of family life" by the Supreme Court "[s]ince its early due process cases dealing with the education and rearing of children").

${ }^{4}$ See Pierce v. Soc'y of Sisters, 268 U.S. 510, 534-35 (1925) (discussing the inability of the state to "unreasonably interfere[] with the liberty of parents and guardians to direct the upbringing and education of children under their control"); Meyer, 262 U.S. at 399-401 (applying a substantive due process analysis to find a fundamental right and liberty interest for parents to control the education of their children).

${ }^{5}$ See, e.g., Morse v. Frederick, 551 U.S. 393, 413 (2007) (discussing the historical applications of the "legal doctrine of in loco parentis [as a mechanism for] courts [to uphold] the right of schools to discipline students, to enforce rules, and to maintain order"); Pierce, 268 U.S. at 535 ("The child is not the mere creature of the State; those who nurture him and direct his destiny have the right, coupled with the high duty, to recognize and prepare him for additional obligations.”).

${ }^{6}$ See Mary Ann Glendon \& Raul F. Yanes, Structural Free Exercise, 90 Mich. L. REV. 477, 547 (1991) (discussing the "threat[] by modern society's 'hydraulic' pressures toward conformity" in the light of the "potential for tyranny in state control of education" and the underestimation of "the extent to which the public schools themselves depend[]... on the support of and interaction with families and surrounding communities").

${ }^{7}$ See William N. Eskridge, Jr., No Promo Homo: The Sedimentation of Antigay Discourse and the Channeling Effect of Judicial Review, 75 N.Y.U. L. REV. 1327, 1359 (2000) ("The most popular situs for no promo homo policies has been public education."). 
These pejoratively deemed "no promo homo" laws 8 currently exist in nine states..$^{9}$ Although the language and content of these state laws vary, ${ }^{10}$ this type of stigmatizing legislation requires schools to provide a curriculum that explicitly or implicitly delineates the norm of sexual orientation as heterosexuality to the exclusion of other types of sexual orientation, ${ }^{11}$ and, in certain states, to the derision or inaccurately claimed criminalization of LGBTQI relationships. ${ }^{12}$

Although these discriminatory statutes that govern public educational settings were often passed under the premise of the protection of the family, ${ }^{13}$ these laws actually do the converse: they harm families. ${ }^{14}$ They harm LGBTQI individuals and their children by delegitimizing the very nature of their own familial structures. ${ }^{15}$ This type of harm results in negative educational

8 See id. at 1328-29 (explaining how the "slogan" of post 1960s' "antigay discourse" that supports stigmatizing legislation is "“no promotion of homosexuality.' In slang, no promo homo."). These stigmatizing laws now extend to discrimination against all types of nonheterosexual conduct. See Kenji Yoshino, The Epistemic Contract of Bisexual Erasure, 52 StAN. L. REV. 353, 366-67 (2000) (discussing how "no promo homo" laws "also prohibit the promotion of bisexuality").

${ }^{9}$ See "No Promo Homo" Laws, Gay, Lesbian \& Straight Educ. Network, http://www.glsen.org/learn/policy/issues/nopromohomo [http://perma.cc/6SQF-W6XL] (listing Alabama, Arizona, Louisiana, Mississippi, Oklahoma, South Carolina, Texas, and Utah as states that still retain these types of laws that prohibit the promotion of homosexuality in the state public schools); see also N.C. GEN. STAT. § 115C-81(e1)(4)(e) (2013) (prescribing the required "reproductive health and safety education program" to include " $\mathrm{t}] \mathrm{each}[\mathrm{ing}]$ that a mutually faithful monogamous heterosexual relationship in the context of marriage is the best lifelong means of avoiding sexually transmitted diseases, including HIV/AIDS" (emphasis added)).

10 See infra Part II (providing the text of state statutes that stigmatize or prohibit the teaching of LGBTQI relationships in schools).

${ }^{11}$ See, e.g., S.C. CODE ANN. § 59-32-30(A)(5) (2004) (providing that the state public schools' comprehensive health education "program of instruction ... may not include a discussion of alternate sexual lifestyles from heterosexual relationships including, but not limited to, homosexual relationships except in the context of instruction concerning sexually transmitted diseases").

12 See, e.g., ALA. CODE $\S 16-40 \mathrm{~A}-2(\mathrm{c})(8)$ (2012) (requiring "[a]n emphasis, in a factual manner and from a public health perspective, that homosexuality is not a lifestyle acceptable to the general public and that homosexual conduct is a criminal offense under the laws of the state" in sexual education or sexually transmitted diseases instruction).

13 See Eskridge, supra note 7, at 1337-38 (framing the proponents of "no promo homo" arguments as viewing "sexual orientation antidiscrimination laws as infringing on their family values").

${ }^{14}$ See Ruthann Robson, Our Children: Kids of Queer Parents \& Kids Who Are Queer: Looking at Sexual Minority Rights from a Different Perspective, 64 ALB. L. REV. 915, 945 (2001) (discussing the harm of LGBTQI discriminatory laws and legal rhetoric for "children of sexual minority parents").

${ }^{15}$ See Jeffrey A. Redding, Dignity, Legal Pluralism, and Same-Sex Marriage, 75 BROOK. L. REV. 791, 842 n.168 (2010) (denoting the pejorative use of the term "lifestyle" in many of the educational statutes that stigmatize LGBTQI relationships). 
outcomes for all students, ${ }^{16}$ as well as bullying and harassment of those students who are perceived to have non-normative families. ${ }^{17}$ The pernicious stereotyping and derogatory implications of these states' LGBTQI stigmatizing legislation are significant, ${ }^{18}$ and they should not mandate the inclusion of such discriminatory content within any public school's curriculum.

One could argue that these types of education laws will soon become a nullity based on the existence of the statutes in less than twenty percent of the states, ${ }^{19}$ the appearance of a lack of political capital to pass even more comprehensive laws that bar instruction of LGBTQI relationships in public schools, ${ }^{20}$ the availability to exercise statutory opt-out or opt-in provisions regarding the health education curriculum that features these discriminatory laws, ${ }^{21}$ and the recent 5-4 Supreme Court decision in Obergefell v. Hodges that determined state same-sex marriage bans are unconstitutional. ${ }^{22}$ However, none of these avenues of potential recourse will likely nullify the educational laws that stigmatize the teaching of any nonheterosexual relationships in the context of family, sex, and marriage. First, it is very unlikely that these laws will be amended in a nondiscriminatory way via legislative action, given their treatment by the state legislatures and the historical nature of these states'

16 See, e.g., Marcel Neergaard, Different, Huffington Post (Mar. 10, 2014), http://www.huffingtonpost.com/marcel-neergaard/LGBTQIq-teen-story_b_4934806.html? ir=Teen [http://perma.cc/PGN7-4VBG] (discussing how a teacher incorrectly informed students in the classroom that "talking about being gay in the classroom is illegal in Tennessee" based on a misunderstanding of the unsuccessful Tennessee "Don't Say Gay" bill).

${ }^{17}$ See Stephen Elkind \& Peter Kauffman, Gay Talk: Protecting Free Speech for Public School Teachers, 43 J.L. \& EDUC. 147, 151 (2014) ("When teachers are unable to discuss homosexuality in the classroom, they cannot effectively protect their students from bullying or anti-gay speech.”); David Gröshöff, Child, Please-Stop the Anti-Queer School Bullycides: A Modest Proposal to Hoist Social Conservatives by Their Own "God, Guns, and Gays" Petard, 11 U. MD. L.J. RACE, RELIGION, GENDER \& Class 151, 200-01 (2011) (linking "no promo homo" laws to hostile schoolground violence).

${ }^{18}$ See Elkind \& Kauffman, supra note 17, at 152-53 (arguing in the context of "no promo homo" educational laws that "[w]hen students in a minority group are stigmatized because of their nonconformity, they experience increased levels of stress, leading to greater likelihood for mental health issues . . . including higher rates of depression, suicide, substance abuse, and even cancer").

${ }^{19}$ See Nancy J. Knauer, LGBT Elder Law: Toward Equity in Aging, 32 HARV. J.L. \& GENDER 1, 35 (2009) (providing that "no promo homo" educational laws only exist in "a handful of states").

${ }^{20}$ See Paige Hamby Barbeauld, "Don't Say Gay" Bills and the Movement to Keep Discussion of LGBT Issues Out of Schools, 43 J.L. \& EDUC. 137, 140 (2014) (discussing the defeat of the proposed, expansive Missouri and Tennessee "Don't Say Gay" bills for the public school curriculum); infra text accompanying notes 35-39.

21 See infra text accompanying notes 205-18.

${ }^{22}$ See Obergefell v. Hodges, 135 S. Ct. 2584, 2607 (2015). 
regulation of marriage and families. ${ }^{23}$ Further, statutory opt-out or opt-in provisions do not fully remediate the harm perpetuated by the "no promo homo" curricular laws. ${ }^{24}$ Finally, even though the Supreme Court has struck down state marriage bans as being unconstitutional and now requires states to recognize same-sex marriages, ${ }^{25}$ the Obergefell decision, in and of itself, does not directly affect the continued existence and enforcement of these discriminatory educational laws. ${ }^{26}$

Therefore, given that the legal definition of family has become a contested concept and given the continued existence of laws that prohibit instruction of LGBTQI relationships in public schools, this tension in school curricula across the nation presents constitutional issues that are ripe for judicial disposition. ${ }^{27}$ Although there has been a limited amount of recent scholarship arguing that laws that stigmatize or prohibit the teaching of LGBTQI relationships in public schools could be the subject of constitutional challenges by LGBTQI students $^{28}$ and some broader critique of abstinence-only-curricula legislation as being violative of the Equal Protection Clause, ${ }^{29}$ almost no scholarly attention has been paid to the potential that these laws could be challenged via

23 See, e.g., Alan Yuhas \& Tom Dart, Gay Marriage Faces Southern Rebellion as Couples Hit State Bureaucracy's Wall, GUARDIAN (June 27, 2015), http://www.the guardian.com/us-news/2015/jun/27/gay-marriage-southern-backlash-supreme-court-ruling [http://perma.cc/Q7WK-YM2K] (discussing the official state resistance to Obergefell in two states, Texas and Louisiana, that still retain discriminatory "no promo homo" educational laws).

${ }^{24}$ See infra text accompanying notes 193-218.

25 See Obergefell, 135 S. Ct. at 2607-08.

26 See Kenji Yoshino, Covering, 111 YALE L.J. 769, 811 (2002) (noting how educational laws that stigmatize nonheterosexual relationships "can coexist with lawssometimes in the same jurisdiction-that protect adult homosexuals").

27 See Douglas NeJaime, Inclusion, Accommodation, and Recognition: Accounting for Differences Based on Religion and Sexual Orientation, 32 HARV. J.L. \& GENDER 303, 333 (2009) ("Given the relatively recent emergence of this issue and the lack of consensus among parents, students, and school officials, curricular issues relating to sexuality are highly contested.").

${ }^{2}$ See, e.g., Michael Boucai, Sexual Liberty and Same-Sex Marriage: An Argument from Bisexuality, 49 SAN DIEGO L. REV. 415, 484-85 (2012) (characterizing "a claim in constitutional challenges to 'No Promo Homo' restrictions on sex education that a preference for heterosexually active citizens cannot justify condemning or ignoring homosexuality and bisexuality" as one of the "gay rights movement['s] . . long-term goals and strategies for the post-Lawrence era"); Ashley E. McGovern, Note, When Schools Refuse to "Say Gay": The Constitutionality of Anti-LGBTQ "No-Promo-Homo" Public School Policies in the United States, 22 CoRnell J.L. \& PuB. PoL'y 465, 469 (2012) (arguing for constitutional challenges to state "no promo homo" curricular laws by LGBTQ students).

${ }^{29}$ See, e.g., Cornelia T.L. Pillard, Our Other Reproductive Choices: Equality in Sex Education, Contraceptive Access, and Work-Family Policy, 56 EMORY L.J. 941, 958 (2007) ("The equal protection critique of abstinence-only curricula is strengthened and rendered more amenable to judicial resolution by the fact that sex education classes are designed not only to expose students to ideas, but also to shape student behavior."). 
a constitutional lawsuit brought by the children of LGBTQI parents. ${ }^{30}$ This Article seeks to fill this void by exploring the viability of this type of litigation as a means to finally end the perpetuation of laws that stigmatize nonheterosexual relationships in public schools.

The central thesis of this Article is that there is a viable foundation for student-centered, federal constitutional challenges to legislation that stigmatizes or prohibits the teaching of LGBTQI relationships in public schools. Essentially, these laws could be successfully challenged by children of LGBTQI parents on equal protection grounds with a claim of a protected class status subject to elevated scrutiny akin to the schoolchildren protected in Plyler v. Doe. ${ }^{31}$ Even if the judiciary is not prepared to afford the children of these families heightened constitutional protections in the context of "no promo homo" educational laws, this stigmatizing legislation would likely not be able to withstand the deferential level of rational basis review, as these laws are paradigmatic of the type of animus that cannot survive this type of constitutional scrutiny. ${ }^{32}$ Through the advancement of student lawsuits, constitutional educational equality can be achieved by nullifying discriminatory laws that define the nature of the family itself - a structure that has been deemed to have constitutional significance for over a century of American jurisprudence. ${ }^{33}$

\section{State Legislation That Stigmatizes oR ProhiBits the TEACHING OF LGBTQI RELATIONSHIPS IN PUBLIC SCHOOLS}

Over the last three years, proposed legislation that stigmatizes, prohibits, or penalizes the teaching of nonheterosexual relationships to public school students has received significant attention in the United States. ${ }^{34}$ Two of the most recent and comprehensive attempts to pass this type of legislation were the proposed 2012 and subsequent 2013 Tennessee bills, the "Classroom Protection Act" (popularly known as the "Don't Say Gay" bills), ${ }^{35}$ which prohibited any pre-K through eighth grade "classroom instruction, course

\footnotetext{
${ }^{30}$ See infra note 248.

31 Plyler v. Doe, 457 U.S. 202, 219 (1982); see also infra Part IV.

32 See, e.g., Romer v. Evans, 517 U.S. 620, 623-24, 632 (1996) (finding that a Colorado constitutional amendment adopted by referendum that expressly discriminated against the LGBT community was premised on only "animus toward the class it affects" and therefore "lack[ed] a rational relationship to legitimate state interests"); see also infra

33 See Moore v. City of E. Cleveland, 431 U.S. 494, 503 (1977) (plurality opinion) ("[T]he Constitution protects the sanctity of the family precisely because the institution of the family is deeply rooted in this Nation's history and tradition.").

${ }^{34}$ See, e.g., Meredith Bennett-Smith, Tennessee 'Don't Say Gay' Bill Is Back, Now Requires Teachers to Tell Parents if Child Is Gay, Huffington Post (Jan. 30, 2013), http://www.huffingtonpost.com/2013/01/30/tennessee-dont-say-gay-bill_n_2582390.html [http://perma.cc/9HB9-WFLS].

35 See id.
} Part IV. 
materials or other informational resources that are inconsistent with natural human reproduction." 36 In 2012, Republican lawmakers in Missouri attempted to pass a similar bill, which provided that "no instruction, material, or extracurricular activity sponsored by a public school that discusses sexual orientation other than in scientific instruction concerning human reproduction shall be provided in any public school." 37 Ultimately, both bills failed to be enacted into law, ${ }^{38}$ after protests and divided commentary. ${ }^{39}$

In an international context, Russia received negative attention when it enacted an "anti-propaganda law" in the context of sexual orientation in June 2013.40 Specifically, Article 6.21 made illegal the promotion of "nontraditional sexual relations among minors, expressed in dissemination of information aimed at developing non-traditional sexual juvenile facilities, attractiveness of non-traditional sexual relations, a distorted picture of the social equivalence of traditional and non-traditional sexual relations, or the imposition of information on non-traditional sexual relationships, causing interest in such relationships." 41 There were calls for a variety of boycotts of the Sochi Olympics in response to the enactment of the law, ${ }^{42}$ and President Barack Obama publicly pronounced his disdain for Article 6.21.43

${ }^{36}$ H.B. 1332, 108th Gen. Assemb., Reg. Sess. (Tenn. 2013); S.B. 234, 108th Gen. Assemb., Reg. Sess. (Tenn. 2013).

${ }^{37}$ H.B. 2051, 96th Gen. Assemb., 2d Reg. Sess. (Mo. 2012).

38 The Tennessee bill died in a House subcommittee. See Katie McDonough, Tennessee “Don't Say Gay” Bill Dies, Again, SALON (Mar. 27, 2013), http://www.salon.com/ 2013/03/27/tennessee_dont_say_gay_bill_dies_again/[http://perma.cc/E76W-QGVB]. The Missouri bill also died in a House subcommittee. See Bennett-Smith, supra note 34 (discussing the failure of the Missouri bill to pass).

${ }^{39}$ Barbeauld, supra note 20, at 140 ("Though both the Tennessee and Missouri bills enjoyed considerable GOP support in committee, each bill was defeated because of strong public backlash against the perceived homophobia associated with the legislation and its supporters." (footnote omitted)).

${ }^{40}$ See, e.g., Kathy Lally, Russia Anti-Gay Law Casts a Shadow over Sochi's 2014 Olympics, WASH. POST (Sept. 29, 2013), http://www.washingtonpost.com/world/russiaanti-gay-law-casts-a-shadow-over-sochis-2014-olympics/2013/09/29/3646344c-27a6-1 e39372-92606241ae9c_story.html [http://perma.cc/ZE6D-K7GQ].

${ }^{41}$ KodEKS RosSIIKOI FEDERATSII RF OB ADMINISTRATIVNYKH PRAVONARUSHENIIAKH [KOAP RF] [Code of Administrative Violations] art. 6.21, http://pravo.gov.ru/proxy/ ips/?docbody $=\&$ nd $=102074277$ \&intelsearch $=\mathrm{N}+195-\mathrm{FZ}+$ of $+30.12 .2001 \quad$ [http://perma.cc/ LB8N-9KSE], translated in ARTIClE 19, RUSSIA: FEDERAL LAWS INTRODUCING BAN OF Propaganda of Non-Traditional SeXual Relationships 11 (June 2013), http:// www.article19.org/data/files/medialibrary/37129/13-06-27-russia-LA.pdf [http://perma.cc/ CP3L-DMZ4].

42 See, e.g., Tanya Domi, Opinion, Send Athletes to the Sochi Olympics, but Boycott the Games, N.Y. TIMES (Feb. 6, 2014), http://www.nytimes.com/roomfordebate/2014/02/ $06 /$ when-should-countries-boycott-the-olympics/send-athletes-to-the-sochi-olympics-butboycott-the-games [http://perma.cc/VX33-3XY4].

43 See Mark Adomanis, Barack Obama's Surprising Lack of Patience for Russia's Anti-Gay Laws, ForBES (Aug. 9, 2013), http://www.forbes.com/sites/markadomanis/2013/ 
Significantly, though, while these three examples of proposed or enacted laws that stigmatize LGBTQI relationships received a considerable amount of attention and rhetoric, ${ }^{44}$ similarly pernicious laws have been and are still in state codes and educational policy guidelines throughout the United States. ${ }^{45}$ The original genesis of these types of laws was the November 1978 Briggs Initiative ${ }^{46}$ - a California state ballot referendum that allowed the termination of any public school employee who participated in "advocating, soliciting, imposing, encouraging or promoting of private or public homosexual activity directed at, or likely to come to the attention of, schoolchildren and/or other employees." 47 While the Briggs Initiative ultimately failed in California, ${ }^{48}$ other states began to adopt similar legislation that discriminated against the teaching of LGBTQI relationships. ${ }^{49}$

Currently, nine states retain educational laws that either prohibit the teaching of nonheterosexual relationships or mandate the express or implied stigmatization of such relationships in school curriculum. ${ }^{50}$ These states are

08/09/barack-obamas-surpsrising-lack-of-patience-for-russias-anti-gay-laws/ [http://perma.cc/ 9EH9-M64W].

${ }^{44}$ See Bijal Shah, LGBT Identity in Immigration, 45 Colum. HuM. RTS. L. REV. 100, 171 (2013) (noting how "vague [political] rhetoric" in the United States that "tout[s] a general commitment to human rights" is often inconsistent with state policy).

${ }^{4}$ See Ian Ayres \& William Eskridge, Opinion, U.S. Hypocrisy over Russia's AntiGay Laws, WASH. POST (Jan. 31, 2014), http://www.washingtonpost.com/opinions/ushypocrisy-over-russias-anti-gay-laws/2014/01/31/3df0baf0-8548-11e3-9dd4-e7278db80d86 _story.html [http://perma.cc/M6ZS-NBGU] (noting the hypocrisy of American governmental criticism to Russia's Article 6.21 when "no promo homo" state laws still exist in the United States).

46 See Nan D. Hunter, Identity, Speech, and Equality, 79 VA. L. REV. 1695, 1702-03 (1993) (designating the Briggs Initiative as the source of the "no promo homo" campaign). Some scholars argue that although the Briggs Initiative was intended to "purge gay teachers from the public schools," its introduction and failure importantly "introduced gay identity into the political sphere." Ari Ezra Waldman, Marriage Rights and the Good Life: A Sociological Theory of Marriage and Constitutional Law, 64 HASTINGS L.J. 739, 761 (2013).

${ }^{47}$ Cal. Proposition 6, § 3(b)(2) (1978) (School Employees. Homosexuality. Initiative Statute.).

${ }^{48}$ See William N. Eskridge, Jr., Body Politics: Lawrence v. Texas and the Constitution of Disgust and Contagion, 57 FLA. L. REV. 1011, 1019 (2005) (describing the failure of the Briggs Initiative in November 1978 as a "rout" and highlighting thenGovernor Ronald Reagan's opposition to the referendum as a contributing factor to its failure).

${ }^{49}$ See Nan. D. Hunter, Censorship and Identity in the Age of AIDS, in IN CHANGING Times: GAY MEN AND LeSBIANS ENCOUNTER HIV/AIDS 39, 48 (Martin P. Levine et al. eds., 1997) (stating that the Briggs Initiative language and intent "became the model for many antigay legislative initiatives, in the United States," including the public school curricular laws that stigmatize any type of relationship other than a heterosexual one).

50 See "No Promo Homo" Laws, supra note 9 (claiming that eight states retain these types of laws in their state codes). Although the Gay, Lesbian \& Straight Education Network (GLSEN) states that North Carolina repealed its stigmatizing law regarding 
Alabama, Texas, Mississippi, Oklahoma, South Carolina, Arizona, Utah, Louisiana, and North Carolina. Aside from official state legislation, local school boards of education also often have considerable discretion with respect to the teaching of sexuality. ${ }^{51} \mathrm{~A}$ complete discussion of the text of each state's stigmatizing laws is necessary in order to illustrate the full scope of the discrimination that is inherent within them and provide the foundation for how they should be subject to constitutional attack. ${ }^{52}$

Alabama's statute is paradigmatic of "no promo homo" laws in public education, and it is particularly egregious given its inaccurate discussion of the allegedly criminal nature of homosexuality. Specifically, the Code of Alabama provides that sexual education and sexually transmitted diseases instruction "should include... [a]n emphasis, in a factual manner and from a public health perspective, that homosexuality is not a lifestyle acceptable to the general public and that homosexual conduct is a criminal offense under the laws of the state." 53 Additionally, this curriculum should include "[c]omprehensive instruction in parenting skills and responsibilities," 54 which furthers the ideology that only a man and a woman in a heterosexual relationship are acceptable parents under state law. Alabama does provide a parental opt-out provision that extends to AIDS/HIV education, but that claim to exemption must be premised on "a signed statement that the teaching of disease, its symptoms, development and treatment and the use of instructional aids and materials of such subjects conflict with the religious teachings of his church." 55

Despite the Supreme Court's holding that a state statute that criminalized consensual "sexual intimacy by same-sex couples" was violative of the Due Process Clause in Lawrence $v$. Texas in 2003,56 thereby invalidating Alabama's sex education statutory provision regarding the criminalization of homosexuality, the Alabama legislature appears intent on retaining its version of stigmatizing and inaccurate legislation. ${ }^{57}$ Two attempts in 2013 and 2014 by State Representative Patricia Todd, the first openly LGBTQI legislator in the state, to strike the discriminatory and false provision from the Alabama sex

LGBTQI relationships, id., the current North Carolina statute continues to implicitly stigmatize any relationship outside of a heterosexual relationship. See N.C. GEN. STAT. $\S 115 \mathrm{C}-81(\mathrm{e} 1)(4)(\mathrm{e})(2013)$.

51 Yishai Blank \& Issi Rosen-Zvi, The Geography of Sexuality, 90 N.C. L. REV. 955, 992-93 (2012) (noting the discretion of local school boards of education in setting public school curriculums as to "how favorable or hostile the curriculum is to homosexuality").

52 See infra Part IV.

53 ALA. CODE $\S 16-40$ A-2(c)(8) (2012).

${ }^{54}$ Id. $\S 16-40 \mathrm{~A}-2(\mathrm{c})(9)$.

55 Id. $\S 16-41-6$.

${ }^{56}$ Lawrence v. Texas, 539 U.S. 558, 564, 578-79 (2003).

57 See Tobin A. Sparling, Judicial Bias Claims of Homosexual Persons in the Wake of Lawrence v. Texas, 46 S. TEX. L. REV. 255, 287-88 (2004) (discussing the history of intolerance as expressed in state law towards LGBTQI individuals in Alabama). 
education curriculum statute were unsuccessful. ${ }^{58}$ Representative Todd has proposed the same amendment in the 2015 Regular Session, and it has been referred to the House Committee on Education. ${ }^{59}$ Based on the legislature's historical treatment of LGBTQI individuals, it seems that this bill will also not be successful in changing the Alabama statute. ${ }^{60}$ The law's continued existence as the curricular standard for the state's public schools that provide sex and HIV/AIDS education ${ }^{61}$ demeans any family that does not fit a heterosexual model. ${ }^{62}$

Texas, the very situs for Lawrence, ${ }^{63}$ also still retains educational laws regarding AIDS/HIV awareness and sex education curricula that stigmatize nonheterosexual relationships and falsely claim the criminalization of "homosexual conduct." 64 In the state's laws regarding an education program for minors regarding AIDS/HIV, there is a provision that requires that " $\mathrm{t}] \mathrm{he}$ materials in the education programs intended for persons younger than 18 years of age must... state that homosexual conduct is not an acceptable lifestyle and is a criminal offense under Section 21.06, Penal Code." 65 Similarly, with respect to required instructional elements related to "sexual education or sexually transmitted diseases," the Texas code requires the inclusion of an "emphasis, provided in a factual manner and from a public health perspective, that homosexuality is not a lifestyle acceptable to the general public and that homosexual conduct is a criminal offense under Section 21.06, Penal Code." 66 Texas parents do retain the right to remove their children from the classroom if the school activity, which includes sex and AIDS/HIV instruction, "conflicts with the parent's religious or moral beliefs." 67

Legislative reformation of these discriminatory curricular laws is unlikely in Texas. In the twelve years since the Supreme Court declared section 21.06

\footnotetext{
${ }^{58}$ See Lila Shapiro, Patricia Todd, Alabama's Openly Gay Lawmaker, Discusses Reelection, GOP Colleagues and Why She'd Never Leave Her State, HufFInGTON PosT (Mar. 27, 2014), http://www.huffingtonpost.com/2014/03/26/patricia-todd_n_5029428.html [http://perma.cc/2GTD-DWL8] (discussing the 2013 bill's failure to leave committee and the 2014 refusal of the chair of the House Committee on Education Policy to calendar the bill); see also H.B. 139, 2014 Leg., Reg. Sess. (Ala. 2014) (providing the proposed deletion of the stigmatizing language at issue within Alabama's current sex education curriculum law).

${ }^{59}$ See H.B. 252, 2015 Leg., Reg. Sess. (Ala. 2015).

60 See supra note 58. (2012).

${ }^{61}$ Alabama does not mandate the teaching of sex education. See ALA. CoDE $\S 16-41-8$

62 See Lawrence v. Texas, 539 U.S. 558, 575 (2003) (discussing the discriminatory and demeaning effect of legal restrictions on homosexual relationships).

${ }^{63}$ See id. at 578-79 (declaring Texas Penal Code section 21.06 unconstitutional).

64 TeX. HEALTH \& SAFETy CODE ANN. $\S \S 85.007$ (b)(2), 163.002(8) (West 2010).

65 Id. $\S 85.007(\mathrm{~b})(2)$.

${ }^{66}$ Id. § 163.002(8).

${ }^{67}$ EDUC. $\$ 26.010$ (a) (West 2012).
} 
of the Texas Penal Code unconstitutional in Lawrence, the Texas legislature has failed to remove the invalid statute from its books, ${ }^{68}$ despite an annotation noting it was "declared unconstitutional." 69 While bills proposing the repeal of section 21.06 and removal of the stigmatizing provisions of the curricular laws have been introduced in the Texas House and Senate for the Eighty-Fourth Legislature of $2015,{ }^{70}$ it seems unlikely that these proposed amendments will be successful given the partisan intransigence of the Texas Legislature regarding the removal of the sodomy statute that was declared unconstitutional by the Supreme Court in 2003.71

Although Mississippi does not explicitly claim criminalization of homosexual conduct in its curricular laws, it does implicitly refer to the invalidated sodomy law that the state still retains in its code as a required component of public schools' "abstinence-only or abstinence-plus education." 72 Specifically, the state requires, as a component of its abstinenceonly education curriculum, instruction in "the current state law related to sexual conduct, including forcible rape, statutory rape, paternity establishment, child support and homosexual activity." 73 This curricular statute refers to section 97-29-59 of the Mississippi Code, which criminalizes sodomy and which remains part of the Code despite the Supreme Court's holding in Lawrence. ${ }^{74}$ Specifically, Mississippi's criminal code defines sodomy as a "detestable and abominable crime against nature committed with mankind or with a beast." 75 Given the implicit reference to the sodomy statute and the codified inclusion of "homosexual activity" with a variety of criminal activity in the Mississippi educational statute, it is clear that this statute stigmatizes any type of LGBTQI sexual or familial activity as it equates nonheterosexual

68 See Jason Brandeis, The Continuing Vitality of Ravin v. State: Alaskans Still Have a Constitutional Right to Possess Marijuana in the Privacy of Their Homes, 29 ALASKA L. REV. 175, 200 n.157 (2012) (describing Texas Penal Code section 21.06 as one example of "'dead letter' statutes [that] have remained on the books long after they were struck down or were recognized as unenforceable").

69 Tex. Penal Code AnN. § 21.06 (West 2011).

70 See H.B. 553, 84th Leg., Reg. Sess. (Tex. 2015) (calling for the repeal of section 21.06 of the Texas Penal Code and sections 85.007(b)(2) and 163.002(8) of the Texas Health \& Safety Code); S.B. 148, 84th Leg., Reg. Sess. (Tex. 2015) (same).

${ }^{71}$ See Tim Murphy, The Unconstitutional Anti-Gay Law that Just Won't Die, MOTHER JONES (Apr. 13, 2011), http://www.motherjones.com/politics/2011/04/lawrencetexas-homosexual-conduct-statute [http://perma.cc/MF6H-ELBM] (discussing the partisan legislative resistance to past proposals to remove the unconstitutional section 21.06 from the Texas Penal Code).

72 See Miss. CODE ANN. § 37-13-171(2)(e) (2013).

${ }^{73} \mathrm{Id}$.

${ }^{74}$ See id. § 97-29-59 (2014).

${ }^{75}$ Id.; see also Corinna Barrett Lain, Upside-Down Judicial Review, 101 GEO. L.J. 113, 169 n.346 (2012) (including Mississippi as one of the "states [that] still criminalize[s] so-called 'crimes against nature"'). 
activity with "crimes against nature," "forcible rape," and "statutory rape."76 Parents are required to opt in for any instruction on human sexuality at school; specifically, parents must be given one week's written notice of this instruction that "inform[s] the parents of their right to request the inclusion of their child for such instruction" and requires the excuse of such children from the instruction "without detriment to the student."77

The "no promo homo" Mississippi curricular law has no current, pending amendments with respect to the stigmatizing language. Instead, there are two pending amendments regarding the discussion of abortion in sexual education instruction $^{78}$ and regarding the usage of abstinence-only/abstinence-plus education as part of "home economics/family dynamics ... instruction on teen pregnancy prevention."79 Given the continued retention of its unlawful sodomy statute, ${ }^{80}$ it seems unlikely that Mississippi will amend its educational statutory mandates that reflect the "no promo homo" ideology. ${ }^{81}$

Other state educational laws that stigmatize LGBTQI relationships require false instruction from a purported public health perspective. Essentially, some of these statutes equate all nonheterosexual relationships with contagion, ${ }^{82}$ disease, ${ }^{83}$ and high-risk-seeking activity. ${ }^{84}$ For example, Oklahoma's required

76 See Miss. CoDE ANN. §§ 37-13-171(2)(e), 97-29-59; see also Dru Stevenson, Costs of Codification, 2014 U. ILL. L. REV. 1129, 1131-36 (discussing the norm of codification as the proximate inclusion of related topical subject matter and identifying the problematic hyperlexis that ordinary citizens endure as a result of the proliferation of codification in the United States).

${ }^{77}$ Miss. CODE ANN. § 37-13-173 (2013).

78 See H.B. 628, 2015 Leg., Reg. Sess. (Miss. 2015).

${ }^{79}$ See H.B. 98, 2015 Leg., Reg. Sess. (Miss. 2015).

80 See Dana Liebelson, Why Do So Many States Still Have Anti-Sodomy Laws?, WeEK (Apr. 8, 2013), http://theweek.com/articles/465821/many-states-still-have-antisodomy-laws [http://perma.cc/2UEH-KH74] (discussing state resistance to the repeal of criminal sodomy statutes despite the holding in Lawrence v. Texas).

${ }^{81}$ See Kenneth L. Karst, Religion, Sex, and Politics: Cultural Counterrevolution in Constitutional Perspective, 24 U.C. DAVIS L. REV. 677, 710-11 (1991) (identifying "[t]he main antagonists in these cultural battles" regarding statutes that stigmatize any nonheterosexual activity as being "resistant to halfway solutions" and dedicated to a "zerosum game").

${ }^{82}$ See Nancy J. Knauer, Homosexuality as Contagion: From The Well of Loneliness to the Boy Scouts, 29 HofSTRA L. REV. 401, 473 (2000) (discussing legislative responses in the form of the passage and implementation of "no promo homo" curricular laws to the perspective of "pro-family organizations [that] homosexual acts are synonymous with disease and death").

83 See Kenji Yoshino, Covering: The Hidden Assault on Our Civil Rights 31107, 45 (2006) (Part One, discussing "the continuing vitality of a disease paradigm of homosexuality").

${ }^{84}$ See Zack Ford, 9 States with Anti-Gay Laws That Aren't That Different from Russia's, THINKPROGRESS (Feb. 3, 2014), http://thinkprogress.org/lgbt/2014/02/03/324142 1/9-state-gay-propaganda-laws/ [http://perma.cc/VH73-MU8J] (noting that the "distinction between 'homosexuality activity' and 'promiscuous sexual activity' implies that there is no kind of homosexual activity that is not promiscuous" in the Oklahoma curricular law). 
curriculum for AIDS prevention education requires teaching "students that[] engaging in homosexual activity, promiscuous sexual activity, intravenous drug use or contact with contaminated blood products is now known to be primarily responsible for contact with the AIDS virus." 85 Like Mississippi's codification series terms, Oklahoma's "no promo homo" law equates nonheterosexual activity with promiscuous sexual activity and intravenous drug use. ${ }^{86}$ Under Oklahoma law, school boards are charged with adopting policies and procedures that allow "parents who object to any learning material or activity on the basis that it is harmful [to] withdraw their children from the activity or from the class or program in which the material is used." 87 These beliefs of harm "include[] objection to a material or activity because it questions beliefs or practices in sex, morality or religion." 88 Additionally, school boards are charged with the creation of policies that allow parents to opt out of sex education curricular instruction, ${ }^{89}$ "any instruction . . regarding sexuality... other than formal sex education curricula," 90 and the AIDS instruction that mandates the stigmatizing instruction that is the basis for this state's "no promo homo" law. 91

There is no pending proposed legislation to amend or repeal the current "no promo homo" Oklahoma statute. This is especially significant given the Legislature's 1990 repeal of a prior Oklahoma statute that resembled the language of the Briggs Initiative. ${ }^{92}$ In 1978 - the same year that the Briggs Initiative appeared as a California referendum question - an Oklahoma statute was enacted that provided for the permissible termination of any teacher who engaged in "advocating, soliciting, imposing, encouraging or promoting public or private homosexual activity in a manner that creates a substantial risk that such conduct will come to the attention of school children or school employees." 93 In 1984, in National Gay Task Force v. Board of Education, the United States Court of Appeals for the Tenth Circuit held that this statute was unconstitutionally overbroad under a First Amendment analysis "insofar as it punishes 'homosexual conduct,' as that phrase is defined in the statute to include 'advocating... encouraging or promoting public or private homosexual activity."'94 The Oklahoma Legislature's six-year resistance in removing this unconstitutional statute from its $\operatorname{code}^{95}$ and its passage of its

85 OKLA. STAT. ANN. tit. 70, § 11-103.3(D)(1) (West 2013).

${ }^{86}$ See supra text accompanying notes 73,76 .

87 OKLA. StAT. ANN. tit. 25, § 2003(A)(3) (West Supp. 2015).

${ }^{88} \mathrm{Id}$.

${ }^{89}$ See id. § 2003(A)(4).

${ }^{90} I d . \S 2003(\mathrm{~A})(5)$.

${ }^{91}$ See id. § 2003(A)(7)(g) (citing OKLA. STAT. ANN. tit. 70, § 11-103.3).

92 OKLA. Stat. AnN. tit. 70, § 6-103.15 (1989), repealed by Laws 1989, 1st Ex. Sess., c. $2, \S 122$.

93 Id.; Nat'l Gay Task Force v. Bd. of Educ., 729 F.2d 1270, 1274 (10th Cir. 1984)

(containing the language of the repealed statute).

${ }^{94}$ Nat'l Gay Task Force, 729 F.2d at 1275.

${ }^{95}$ See supra note 92. 
current "no promo homo" law as part of mandated AIDS prevention education in 1987, ${ }^{96}$ three years after the National Gay Task Force decision, ${ }^{97}$ indicate the likely resistance to any proposed removal of the current law that remains an integral part of its health education curriculum. ${ }^{98}$

Similar to its other state counterparts, South Carolina's Code prohibits any positive portrayals of LGBTQI relationships. ${ }^{99}$ Specifically, South Carolina's statutory comprehensive health education program requires the exclusion of any "discussion of alternate sexual lifestyles from heterosexual relationships including, but not limited to, homosexual relationships except in the context of instruction concerning sexually transmitted diseases." 100 In South Carolina, teachers who "refuse[] to comply" with this sexual education curriculum are "subject to dismissal."101 This type of punitive statutory provision has a considerably coercive effect in terms of the teaching or discussion of any nonheterosexual relationships within the schoolhouse door. ${ }^{102}$ It also reflects the Briggs Initiative ideology in the expansive reach of its prohibitions on the speech and teaching of all public school employees, regardless of their own sexual orientation. ${ }^{103}$ Parents have the right to opt their children out of the "health education program [if it] conflicts with the family's beliefs." 104 School districts are charged with the responsibility to not "penalize" or "embarrass" such exempted students. ${ }^{105}$

The South Carolina Legislature, like legislative bodies in the other states that retain similar stigmatizing legislation against LGBTQI relationships,

96 See OKLA. STAT. AnN. tit. 70, § 11-103.3(D)(1).

${ }^{97}$ See Nat'l Gay Task Force, 729 F.2d at 1275.

${ }^{98}$ See Clifford J. Rosky, Fear of the Queer Child, 61 BufF. L. REV. 607, 649 (2013) (noting that "[a]lthough federal courts have continued to invalidate [LGBTQI discriminatory] laws, state legislatures have continued to pass them"- specifically, in the context of "no promo homo" educational laws (footnote omitted)).

${ }^{99}$ See Marc A. Fajer, Can Two Real Men Eat Quiche Together? Storytelling, GenderRole Stereotypes, and Legal Protection for Lesbians and Gay Men, 46 U. MiAmI L. REv. 511, 584 (1992) (identifying the South Carolina LGBTQI stigmatizing statute as an example of a mandate that "[h]igh school sex education courses ... not mention homophile behavior except as a form of deviance that students should avoid").

100 S.C. CODE ANN. § 59-32-30(A)(5) (2004).

${ }^{101}$ Id. $\S 59-32-80$.

102 These types of legislative controls on speech mirror the judicial controls on speech in today's public schools. See Amanda Harmon Cooley, Controlling Students and Teachers: The Increasing Constriction of Constitutional Rights in Public Education, 66 BAYLOR L. REV. 235, 264 (2014) (discussing the evolution of judicial ideology in "the adoption of control mechanisms to constrict the speech of teachers as a way to enforce a prescribed notion of order in the schools").

${ }^{103}$ See William N. Eskridge, Jr., Some Effects of Identity-Based Social Movements on Constitutional Law in the Twentieth Century, 100 Mich. L. REv. 2062, 2179 n.594 (2002) (characterizing the purpose of the 1978 Briggs Initiative as expansively seeking "to bar from public schoolteaching any person who 'advocated' homosexuality in any way").

${ }^{104}$ S.C. CODE ANN. § 59-32-50.

$105 \mathrm{Id}$ 
seems unlikely to amend this discriminatory provision in the near future. ${ }^{106} \mathrm{On}$ June 4, 2015, the statute was amended to add instruction on the subject of domestic violence to the comprehensive health education program for the state's public schools. ${ }^{107}$ The legislative amendment leaves intact the statutory language barring instruction of "alternate sexual lifestyles."108

Arizona's public school sex education curriculum is also pointedly aligned with the "no promo homo" movement's ideological foundation. ${ }^{109}$ A required component of Arizona's curriculum on AIDS is a prohibition on any district "includ[ing] in its course of study instruction which: [p]romotes a homosexual life-style[; p]ortrays homosexuality as a positive alternative life-style[; or s]uggests that some methods of sex are safe methods of homosexual sex."110 Arizona's statute also mandates that its AIDS/HIV curriculum shall "[b]e medically accurate," "[p]romote abstinence," and "[d]ispel myths regarding transmission of the human immunodeficiency virus." 111

Similar to Oklahoma's general opt-out statutory provisions, ${ }^{112}$ Arizona parents have a statutory right to remove children from "any learning material or activity on the basis that it is harmful [which] includes objection to a material or activity because it questions beliefs or practices in sex, morality or religion." 113 Also, similarly, Arizona statute requires school boards to draft procedures to provide specific parental rights to opt out of "any instruction ... regarding sexuality in courses other than formal sex education curricula"114 and instruction regarding AIDS pursuant to section 15-716. ${ }^{115} \mathrm{In}$ addition to these opt-out provisions, Arizona law also mandates an opt-in provision for sex education and AIDS instruction, the latter of which retains the stigmatizing language for nonheterosexual activity. ${ }^{116}$ Like in many of the states that retain these types of laws, there are currently no proposed amendments regarding the discriminatory curricular language before the

106 See, e.g., supra text accompanying note 81.

107 See S. 3, 121 st Gen. Assemb., 1st Reg. Sess. (S.C. 2015) (S.C. Acts 58).

108 See id.; S.C. CODE ANN. § 59-32-30(A)(5).

${ }^{109}$ See Eskridge, supra note 7, at 1343 (discussing the "no promo homo" argument as attempting to appeal to "utilitarian concerns about the sexuality of children, old-fashioned natural law conceptions of acceptable sex or gender roles, and republican concerns about public culture"').

110 ARIZ. REV. STAT. ANN. § 15-716(C) (2014).

${ }^{111}$ Id. $\S 15-716(\mathrm{~B})(2),(3),(5)$.

112 See supra text accompanying notes $87-88$.

113 ARIZ. REV. STAT. ANN. § 15-102(A)(3).

${ }^{114}$ Id. $\S 15-102(\mathrm{~A})(5)$.

115 See id. $\S 15-102(\mathrm{~A})(7)(\mathrm{g})$ (citing id. $\S 15-716(\mathrm{~F})$ ).

116 See id. $\$ 15-102(\mathrm{~A})(4)$ (providing the opt-in requirements of written parental permission for participation in any sex education curricula pursuant to section 15-711 or 15-716). 
Arizona State Legislature, and past efforts to change the educational law have failed. 117

Utah shares several similarities with Arizona in its treatment of LGBTQI relationships as part of its health education curriculum. Specifically, the Utah Code prohibits "instruction in ... the advocacy of homosexuality" as part of the health education curriculum. ${ }^{118}$ Also, like Arizona, Utah retains an opt-in provision for sexual education. ${ }^{119}$ Utah requires parental/guardian permission for students to "participate in human sexuality instruction" and provides for exemption of students from such instruction. ${ }^{120}$ Also, like its neighbor to the south, Utah has no pending proposals to amend the stigmatizing language of its heath education curricular law, despite recent examination of the statute by the legislature as evidenced by an unsuccessful 2013 proposal to included instruction in cardiopulmonary resuscitation in that statute. ${ }^{121}$

Louisiana also retains a statutory provision that discriminates specifically against LGBTQI activity. However, its statutory language is unique among the laws examined in this Article. The Louisiana Code provides that "[n]o sex education course offered in the public schools of the state shall utilize any sexually explicit materials depicting male or female homosexual activity."122 Despite the "no promo homo" language of this statute, the sex education statutory scheme purports to reflect a legislative intent "that 'sex education' shall not include religious beliefs, practices in human sexuality, nor the subjective moral and ethical judgments of the instructor or other persons." 123 Further, "[s]tudents shall not be tested, quizzed, or surveyed about their personal or family beliefs or practices in sex, morality, or religion." 124 In addition to this prohibition on personal surveys of students within the sex education curriculum, Louisiana retains an opt-out provision for parents and guardians to excuse their children from receiving such instruction. ${ }^{125}$ Currently, there are no pending proposals to amend the stigmatizing language of the sex education statute, and a 2014 attempt to eliminate this language died in committee. ${ }^{126}$

117 See S.B. 1457, 50th Leg., 1st Reg. Sess. (Ariz. 2011) (proposing to eliminate the discriminatory LGBTQI language of section 15-716 of the Arizona Code).

118 UTAH CODE ANN. § 53A-13-101(1)(c)(iii)(A)(II) (LexisNexis 2013).

119 See UTAH ADMIN. CODE r. 277-474-1(I) (2015) (providing the opt-in procedures for participation in sexual education instruction).

120 Id.

121 See H.B. 307, 60th Leg., Gen. Sess. (Utah 2013).

122 LA. STAT. ANN. § 17:281(A)(3) (2013).

${ }^{123}$ Id. $\S 17: 281(\mathrm{~A})(2)$.

124 Id.

${ }^{125}$ See id. $\S 17: 281$ (D) ("Any child may be excused from receiving instruction in 'sex education' at the option and discretion of his parent or guardian.").

${ }^{126}$ See H.B. 369, 40th Leg., Reg. Sess. (La. 2014); Final Disposition of House Bills, LA. ST. LEGISLATURE, http://www.legis.la.gov/legis/FinalDisposition.aspx?c=H\&sid=14RS [https://perma.cc/5BES-S9EH]. 
North Carolina is the ninth state that continues to allow state-supported discrimination against nonheterosexual activity in sex education instruction, albeit in an implicit way. ${ }^{127}$ North Carolina is an example of a state that once required express stigmatizing instruction regarding nonheterosexual activity in its sex and HIV/AIDS education curriculum and that has made an attempt to change its law. ${ }^{128}$ However, this statutory amendment does not sufficiently cure all of the discriminatory treatment of LGBTQI families in the state health education curriculum, as the current statutory language still implicitly supports the "no promo homo" perspective. ${ }^{129}$ The original version of North Carolina's law provided that the State Board of Education's instructional objectives for "prevention of sexually transmitted diseases, including... (AIDS) virus infection ... shall teach ... that a mutually faithful monogamous heterosexual relationship in the context of marriage is the best lifelong means of avoiding diseases transmitted by sexual contact, including [AIDS]."130 Further, this original health education statute provided that "[a]ny instruction concerning the causes of sexually transmitted diseases, including [AIDS], in cases where homosexual acts are a significant means of transmission, shall include the current legal status of those acts."131

Although this latter language was amended in 2006, ${ }^{132}$ North Carolina still retains stigmatizing treatment of LGBTQI individuals in its public schools, as it requires "a reproductive health and safety education program commencing in seventh grade" that "[t]eaches that a mutually faithful monogamous heterosexual relationship in the context of marriage is the best lifelong means of avoiding sexually transmitted diseases, including HIV/AIDS."133 Like Arizona, North Carolina has both opt-in and opt-out provisions for parents regarding their children's participation in sex education and HIV/AIDS

${ }^{127}$ Some entities label only eight states, Alabama, Arizona, Louisiana, Mississippi, Oklahoma, South Carolina, Texas, and Utah, as retaining LGBTQI stigmatizing language for public school instruction. See, e.g., "No Promo Homo" Laws, supra note 9 (characterizing these states as retaining "no promo homo" curricular laws).

${ }^{128}$ See \#DontEraseUs: State Anti-LGBT Curriculum Laws, LAMBDA LEGAL, http://www.lambdalegal.org/dont-erase-us/laws [http://perma.cc/KB5J-Q7R6] (discussing North Carolina's 2006 statutory amendment to its express "no promo homo" curricular law).

${ }^{129}$ See Nancy J. Knauer, The Recognition of Same-Sex Relationships: Comparative Institutional Analysis, Contested Social Goals, and Strategic Institutional Choice, 28 U. HAW. L. REV. 23, 30 n.36 (2005) (classifying the problematic, stigmatizing portion of North Carolina's curricular law as its requirement of the "promot[ion of] heterosexual marriage"); see also \#DontEraseUs, supra note 128 (noting that North Carolina's sex education statute "continues to exclude LGBT students").

${ }^{130}$ N.C. GEN. STAT. § 115C-81(e1)(3) (2005), amended by 2006 N.C. Sess. Laws 264, § 54(a)-(c) (current version at N.C. GEN. STAT. § 115C-81(e1)(4) (2013)).

131 Id.

132 See id.

${ }^{133}$ Id. § 115C-81(e1)(4) (2013). 
education instruction. ${ }^{134}$ There are no current, additional proposals to amend or remove the stigmatizing language that is still retained within North Carolina's sex education curriculum laws, despite multiple recent examinations of the statute. ${ }^{135}$

Despite some efforts to effect change with respect to these state laws that stigmatize or prohibit the teaching of LGBTQI relationships in public schools, ${ }^{136}$ these attempts have been unsuccessful in removing the curricular laws from their codes. ${ }^{137}$ Although Alabama, Texas, Mississippi, Oklahoma, South Carolina, Arizona, Utah, Louisiana, and North Carolina compose less than twenty percent of all of the states, the maintenance and implementation of the "no promo homo" laws within those states effectuate an incalculable harm on LGBTQI students and families. ${ }^{138}$ Most proposed reforms of these laws, ranging from legislative action to federal administrative regulations, ${ }^{139}$ are not sufficient on their own to adequately address these damages. Consequently, federal litigation brought by the class of students harmed-children of LGBTQI parents - is the necessary course of action to remedy the constitutional violations of these discriminatory laws. ${ }^{140}$

${ }^{134}$ See id. $\S 115 \mathrm{C}-81(\mathrm{e} 1)(7)$ (requiring a review period for parents of materials related to instruction in sexual education or sexually transmitted diseases and "policies to provide opportunities either for parents and legal guardians to consent or for parents and legal guardians to withhold their consent to the students' participation in any or all of these programs"); id. § 115C-81(e1)(4a) (charging local school boards with "adopt[ing] a policy and provid[ing] a mechanism to allow a parent or a guardian to withdraw his or her child from [sex education] instruction").

135 See, e.g., H.B. 694, 2013 Gen. Assemb., Reg. Sess. (N.C. 2013) (proposing an amendment to section $115 \mathrm{C}-81$ 's specific subsection (e1)(4) but not to the stigmatizing language regarding LGBTQI relationships). Various proposals were introduced to section 115-C81 that were not related to the stigmatizing language regarding LGBTQI relationships. See H.B. 960, 2013 Gen. Assemb., Reg. Sess. (N.C. 2013); H.B. 689, 2013 Gen. Assemb., Reg. Sess. (N.C. 2013); H.B. 633, 2013 Gen. Assemb., Reg. Sess. (N.C. 2013); H.B. 559, 2013 Gen. Assemb., Reg. Sess. (N.C. 2013); H.B. 455, 2013 Gen. Assemb., Reg. Sess. (N.C. 2013); S.B. 708, 2013 Gen. Assemb., Reg. Sess. (N.C. 2013); S.B. 243, 2013 Gen. Assemb., Reg. Sess. (N.C. 2013); S.B. 138, 2013 Gen. Assemb., Reg. Sess. (N.C. 2013).

136 See, e.g., supra text accompanying notes 128-33.

137 See Josh Corngold, Introduction: The Ethics of Sex Education, 63 EDUC. THEORY 439, 440 (2013) (discussing the "strenuous[] resist[ance]" to "appeals for the positive inclusion of lesbian, gay, bisexual, and transgender (LGBT) issues in school curricula").

138 See Hunter, supra note 46, at 1717-18 (discussing the myriad types of harm that "no promo homo" laws inflict upon the LGBTQI and general communities).

${ }^{139}$ See, e.g., McGovern, supra note 28, at 486 (arguing for legislative reforms and federal administrative policy changes as potential solutions to eliminate the current LGBTQI stigmatizing state educational laws).

${ }^{140}$ See, e.g., Griffin v. Cty. Sch. Bd., 377 U.S. 218, 233-34 (1964) (discussing the required need for a federal court order "to assure ... [schoolchildren] their constitutional rights will no longer be denied them" when state action has denied them equal protection). 


\section{THE HARM ENGENDERED BY STATE LEGISLATION That STIGMATIZES OR PROHIBITS THE TEACHING OF LGBTQI RELATIONSHIPS IN PUBLIC SCHOOLS}

The anachronistic and nonempirically based assumptions about nontraditional families ${ }^{141}$ that are reflected by these nine states' LGBTQI stigmatizing curricular laws harm parents, children, and broader communities. ${ }^{142}$ In contrast to the dominant political narrative that underlies the "no promo homo" agenda and that justifies the continued existence of these laws - specifically, that nonheterosexual, familial relationships are harmful to children ${ }^{143}$ - a growing body of research supports the conclusion that the sexual orientation of parents is not a determinative variable in the likelihood of children to thrive. ${ }^{144}$ Additionally, studies have demonstrated that LGBTQI individuals are often more likely to adopt older children, ${ }^{145}$ diverse children, ${ }^{146}$ and children with special needs, ${ }^{147}$ which provides an

${ }^{141}$ See Mark Edward Maxwell \& Gary Kelsey, Second Parent Adoption: Same-Sex and the Best Interest of the Child, 37 J. HeAlth \& HuM. SERvS. AdMIn. 260, 262 (2014) (explaining that " $[\mathrm{t}]$ he National Social Workers Association (NSWA), the Child Welfare League of America (CWLA), and the American Academy of Pediatrics (AAP) are among the organizations that have stated LGBT individuals and couples are as equally qualified as heterosexual individuals and couples to foster and adopt children").

142 See Campaign for S. Equal. v. Bryant, 64 F. Supp. 3d 906, 936 (S.D. Miss. 2014) (classifying the "Mississippi law [that] also requires school districts to teach its preLawrence sodomy law (along with all other State laws regarding homosexuality) to schoolchildren, including children of gay couples" as one example of the historical and current, harmful discrimination against LGBTQI individuals in that state); Barbara Fedders, Coming Out for Kids: Recognizing, Respecting, and Representing LGBTQ Youth, 6 NEV. L.J. 774, 791-92 (2006) (discussing the harm that "no promo homo" educational laws inflict on LGBTQ youth).

${ }^{143}$ See, e.g., Larry Tomczak, Avalanche of Immoral Propaganda Targets Our Youth, CHARISMA NEWS (Jan. 11, 2015), http://www.charismanews.com/opinion/heres-the-deal/4 7834-avalanche-of-immoral-propaganda-targets-our-youth [http://perma.cc/LW3H-ST6K] ("Check out how aggressive these well-funded and well-organized groups are in targeting innocent and impressionable children. In elementary schools, high schools, colleges and the media, LGBTQ advocates are extremely deceptive, sophisticated and strategic in working to lead a generation over the cliff to destruction.").

144 See Judith Stacey \& Timothy J. Biblarz, (How) Does the Sexual Orientation of Parents Matter?, 66 AM. Soc. REV. 159, 160 (2001) (noting that the "research, almost uniformly, reports findings of no notable differences between children reared by heterosexual parents and those reared by lesbian and gay parents, and that it finds lesbigay parents to be as competent and effective as heterosexual parents").

145 See David M. Brodzinsky, Evan B. Donaldson Adoption Inst., Expanding RESOURCES FOR CHILDREN III: RESEARCH-BASED BEST PRACTICES IN ADOPTION BY GAYS AND LESBIANS 5, 33-37 (2011), http://adoptioninstitute.org/old/publications/2011_10_ Expanding_Resources_BestPractices.pdf [http://perma.cc/D244-XCVH] (noting the increased likelihood for LGBT couples to adopt older children).

146 See Rachel H. Farr \& Charlotte J. Patterson, Transracial Adoption by Lesbian, Gay, and Heterosexual Couples: Who Completes Transracial Adoption and with What Results?, 
increased likelihood for family opportunities for children who are often in desperate need for them. ${ }^{148}$ Based on this evidence, there is a developing consensus among the major medical and psychological professional associations that there is a vital need to oppose discrimination against family structures based on sexual orientations found within that family, ${ }^{149}$ as both heterosexual and LGBTQI individuals have the capacity to provide caring, supportive environments for their children. ${ }^{150}$ Consequently, the harm that is at issue when examining the state educational statutes that are categorized as "no promo homo" laws is not an injury that results from being a child in a

12 AdOPTION Q. 187, 199 (2009) (finding that "transracial adoption was more common among same-sex than among other-sex couples").

147 See David M. Brodzinsky, Adoption by Lesbians and Gay Men: A National Survey of Adoption Agency Policies and Practices, in AdOPTION By LESBIANS AND GAY Men: A New Dimension In FAmily Diversity 62, 74 (David M. Brodzinsky \& Adam Pertman eds., 2011) (noting the increased recruitment of lesbian and gay parents by adoption agencies that specialize in placing children with special needs).

148 Even political opponents of the recognition of same-sex adoptions acknowledge the increased likelihood of LGBTQI families adopting older, transracial, or special-needs children. See, e.g., Rhonda Wasserman, Are You Still My Mother?: Interstate Recognition of Adoptions by Gays and Lesbians, 58 AM. U. L. REV. 1, 18 (2008) (noting that a Republican opponent of Oklahoma's potential recognition of out-of-state same-sex adoptions acknowledged that "for some 'older, harder to adopt children, some of whom are in state custody ....,' adoption by an out-of-state gay couple might be their only chance for adoption" (alteration in original) (footnote omitted) (quoting Marie Price, GOP Vows Gay Adoption Law: Lawmakers Hope to Ban Recognition of Out-of-State Adoptions by SameSex Partners, Tulsa World, Mar. 23, 2004, at A14)).

${ }^{149}$ See, e.g., American Academy of Pediatrics Supports Same Gender Civil Marriage, AM. ACAD. PEDIATRICS (Mar. 21, 2013), http://www.aap.org/en-us/about-the-aap/aap-pressroom/Pages/American-Academy-of-Pediatrics-Supports-Same-Gender-Civil-Marriage.aspx [https://perma.cc/3CRQ-9HKV] ("A great deal of scientific research documents there is no cause-and-effect relationship between parents' sexual orientation and children's wellbeing....”); APA Supports Legalization of Same-Sex Civil Marriages and Opposes Discrimination Against Lesbian and Gay Parents, AM. PsYCHOL. AsS'N (July 28, 2004), http://www.apa.org/news/press/releases/2004/07/gay-marriage.aspx [http://perma.cc/W2K24CEW] (stating the American Psychological Association's opposition to discrimination against LGBTQI parents based on research "that parenting effectiveness and the adjustment, development and psychological well-being of children is unrelated to parental sexual orientation").

${ }^{150}$ See Michael J. Rosenfeld, Nontraditional Families and Childhood Progress Through School, 47 DEMOGRAPHY 755, 772 (2010) (concluding "that children raised by same-sex couples have no fundamental deficits in making normal progress through school"); American Academy of Pediatrics Supports Same Gender Civil Marriage, supra note 149 (providing that studies show "normal development of children of same-gender couples when the child is wanted, the parents have a commitment to shared parenting, and the parents have strong social and economic support" and determining that "[c]ritical factors that affect the normal development and mental health of children ... [do not include] the sexual orientation of their parents"). 
nonheterosexual family. ${ }^{151}$ Instead, the harm is the perpetuation of negative stereotypes and discriminatory content against LGBTQI families as a mandated part of sex education curricula within these states. ${ }^{152}$

State laws that stigmatize or prohibit the teaching of LGBTQI relationships damage all family members of nonheterosexual families and entire educational communities. ${ }^{153}$ Like other types of legislation that discriminate based on sexual orientation, these curricular laws injure individuals, families, and communities in many ways. ${ }^{154}$ By demarcating nonheterosexual familial relationships as unacceptable relationships ${ }^{155}$ that are by law inconsistent with sex heterogamy norms, ${ }^{156}$ the expressly stigmatizing educational laws classify students in LGBTQI families as minority groups with outsider or second-tier status. ${ }^{157}$ Significant and serious negative "health outcomes, including poor mental health, decreased well-being, and suicide"

151 See Ellen C. Perrin et al., Am. Acad. of Pediatrics, Promoting the WellBeing of ChILdRen Whose PARents ARE GAY OR Lesbian, at e1377 (2013), http://pediatrics.aappublications.org/content/131/4/e1374.full.pdf [http://perma.cc/4BY2EL9X] (providing that a significant number of scientific studies conclude that children of same-sex parents "fare as well in emotional, cognitive, social, and sexual functioning as do children whose parents are heterosexual").

152 See id. at e1380 (" $[\mathrm{M}]$ ost data suggest that children grow up successfully in families created by gay and lesbian parents despite the almost-universal family disruption and social stigma they have experienced [which] attests to the resilience of these families.").

153 See Ilan H. Meyer \& Ronald Bayer, School-Based Gay-Affirmative Interventions: First Amendment and Ethical Concerns, 103 AM. J. PuB. HeAlth 1764, 1764 (2013) ("[S]tigma and prejudice against LGBT people need to be uprooted from schools because they are social ills that cause harm to LGBT youths (if not the entire school community).").

154 See, e.g., Christopher R. Leslie, Procedural Rules or Procedural Pretexts?: A Case Study of Procedural Hurdles in Constitutional Challenges to the Texas Sodomy Law, 89 KY. L.J. 1109, 1131 (2001) (arguing, pre-Lawrence, that Texas's sodomy law "ultimately stigmatizes and injures gay Texans in myriad ways unrelated to criminal enforcement of the law").

155 See, e.g., ALA. CODE $\S 16-40 \mathrm{~A}-2(\mathrm{c})(8)$ (2012) (requiring the inclusion of "[a]n emphasis ... that homosexuality is not a lifestyle acceptable to the general public" in sex education and sexually transmitted diseases instruction); ARIZ. REV. STAT. ANN. § 15716(C) (2014) (prohibiting any district from "includ[ing] in its course of [AIDS education] study instruction which: [p]romotes a homosexual life-style; [p]ortrays homosexuality as a positive alternative life-style; [or s] uggests that some methods of sex are safe methods of homosexual sex").

156 See Elizabeth F. Emens, Intimate Discrimination: The State's Role in the Accidents of Sex and Love, 122 HARV. L. REV. 1307, 1330-31 (2009) ("From marriage law to sodomy law to 'no promo homo' statutes, this norm [of sex heterogamy] is immediately recognizable in law as well as culture." (footnote omitted) (citing Eskridge, supra note 7)).

157 See Brief for Utah Pride Center et al. as Amici Curiae, Hollingsworth v. Perry, 133 S. Ct. 2652 (2013) (Nos. 12-144, 12-307), 2013 WL 769314, at *9 ("Collectively, these statutes demean same-sex families, teach that treatment of individuals as inherently inferior is acceptable under the law, send denigrating messages to children of same-sex parents, and undermine straight parents whose belief systems accept gay people as equal members of society."). 
can result from this type of "[m]inority stress related to stigma and prejudice against [LGBTQI] people."158 More broadly, these types of "no promo homo" statutes fall within the class of laws that Professor William N. Eskridge, Jr. deems to be "state expression that not only degrades a minority group harmful to no one, but also demonizes the group," thereby resulting in "strongly unrepublican effects - including prejudice against the group, anger on the part of group members, and wasteful status competition."159

Those state statutes that expressly or implicitly prohibit the teaching of any nonheterosexual relationships are equally harmful to students and families. ${ }^{160}$ Professor Kenji Yoshino argues that the detrimental impact of these types of "no promo homo" statutes is that they make LGBTQI individuals, and their family members, legally invisible. ${ }^{161}$ Professor Nan D. Hunter asserts that the harm of these state laws is the "creat[ion of] a form of state orthodoxy"; 162 specifically, Professor Hunter finds that the statutory "selective silencing of certain identities," pursuant to these types of state laws, has a "totalitarian effect of enforcing conformity."163 Further, negative outcomes that flow from the assimilationist ideology of these types of state statutes can include significant declines in mental health. ${ }^{164}$ Finally, prohibitions on dialogue regarding families in educational curricula run contrary to social science findings about the importance of open discussions in ensuring positive, pedagogical outcomes for all students, regardless of the sexual orientation of their parents. ${ }^{165}$

${ }^{158}$ Meyer \& Bayer, supra note 153, at 1764.

${ }^{159}$ Eskridge, supra note 7, at 1376.

160 See, e.g., N.C. GEN. STAT. § 115C-81(e1)(4) (2013) (requiring "a reproductive health and safety education program commencing in seventh grade" that " $\mathrm{t}]$ eaches that a mutually faithful monogamous heterosexual relationship in the context of marriage is the best lifelong means of avoiding sexually transmitted diseases, including HIV/AIDS"); S.C. CODE ANN. §59-32-30(A)(5) (2004) (requiring the exclusion of any "discussion of alternate sexual lifestyles from heterosexual relationships including, but not limited to, homosexual relationships except in the context of instruction concerning sexually transmitted diseases" in its comprehensive health education statute).

161 Yoshino, supra note 8, at 366.

162 Hunter, supra note 46, at 1719.

163 Id.

${ }^{164}$ See Orly Rachmilovitz, Family Assimilation Demands and Sexual Minority Youth, 98 MinN. L. REV. 1374, 1388 (2014) (“As teens struggle with developing their identity, assimilation demands jeopardize a strong sense-of-self and psychological health, resulting in a young person's reduced productivity, depression, and difficulty forming and sustaining intimate relationships.").

165 See Daryl Hannah, Shutting LGBT Students Out: How Current Anti-Bullying Policies Fail America's Youth, 1 LGBTQ PoL'y J. Harv. Kennedy Sch. 85, 90 (2011), http://isites.harvard.edu/icb/icb.do?keyword=k78405\&pageid=icb.page414495 [http://perma.cc/ E7E2-EJ4X] ("This holistic approach to addressing homophobia in schools by creating safe spaces, having open dialogue, and policing bullying has ultimately resulted in both academically and socially better-adjusted students — straight, gay, and transgender."). 
Although no federal court has ever evaluated the constitutionality of any of the nine states' current laws that stigmatize or prohibit instruction regarding nonheterosexual relationships, ${ }^{166}$ a diverse set of federal courts, including the Supreme Court, has recognized the types of harms that legislation inflicts upon LGBTQI families in corollary same-sex marriage and adoption ban cases. ${ }^{167}$ By citing to scientific evidence and medical association reports to support their findings that harm flows to families, not from the nature of the sexual orientation of the parents, ${ }^{168}$ but from the unequal, legal treatment of such families, these courts have highlighted the inequity of LGBTQI discriminatory laws. ${ }^{169}$ Therefore, the Supreme Court and the vast majority of other federal courts that have examined state marriage and adoption ban laws, which are important parallels to the state curricular laws that stigmatize nonheterosexual relationships, are in agreement with the conclusions of the bulk of medical and

166 See William N. Eskridge, Jr., Destabilizing Due Process and Evolutive Equal Protection, 47 UCLA L. REV. 1183, 1213 (2000) (noting that discriminatory curricular laws regarding teaching about LGBTQI relationships "have not even yielded an equal protection challenge at the appellate level").

${ }^{167}$ See, e.g., Obergefell v. Hodges, 135 S. Ct. 2584, 2600-01 (2015) (outlining the harm and humiliation that marriage bans inflict upon the children of same-sex couples); Bostic v. Schaefer, 760 F.3d 352, 383 (4th Cir.), cert. denied, 135 S. Ct. 308, and cert. denied sub nom. McQuigg v. Bostic, 135 S. Ct. 314, and cert. denied sub nom. Rainey v. Bostic, 135 S. Ct. 286 (2014) ("[B]y preventing same-sex couples from marrying, the Virginia Marriage Laws actually harm the children of same-sex couples by stigmatizing their families and robbing them of the stability, economic security, and togetherness that marriage fosters."); De Leon v. Perry, 975 F. Supp. 2d 632, 653 (W.D. Tex. 2014), aff'd sub nom. De Leon v. Abbott, 791 F.3d 619 (5th Cir. 2015) ("[Texas's constitutional marriage ban] causes needless stigmatization and humiliation for children being raised by the loving same-sex couples being targeted....[F]ar from encouraging a stable environment for childrearing, [it] denies children of same-sex parents the protections and stability they would enjoy if their parents could marry.").

168 See Bostic, 760 F.3d at 383 ("“[T] effectiveness is related to parental sexual orientation,' and 'the same factors'-including family stability, economic resources, and the quality of parent-child relationships - 'are linked to children's positive development, whether they are raised by heterosexual, lesbian, or gay parents." (quoting Brief for American Psychological Association, American Academy of Pediatrics, American Psychiatric Association, National Association of Social Workers, and Virginia Psychological Association as Amici Curiae in Support of PlaintiffsAppellees and Intervenors, Bostic v. Schaefer, 760 F.3d 352 (4th Cir. 2014) (Nos. 14-1167 (L), 14-1169, 14-1173), 2014 WL 1510921, at*18, *23)); Varnum v. Brien, 763 N.W.2d 862,899 (Iowa 2009) ("Plaintiffs presented an abundance of evidence and research, confirmed by our independent research, supporting the proposition that the interests of children are served equally by same-sex parents and opposite-sex parents.").

${ }^{169}$ See Kitchen v. Herbert, 755 F.3d 1193, 1215 (10th Cir.), cert. denied, 135 S. Ct. 265 (2014) ("These laws deny to the children of same-sex couples the recognition essential to stability, predictability, and dignity. Read literally, they prohibit the grant or recognition of any rights to such a family and discourage those children from being recognized as members of a family by their peers."). 
social scientific research. ${ }^{170}$ These conclusions are that the major harm to children of same sex couples does not come from the existence of LGBTQI parents, but from the discrimination that these students endure as a result of the state-sponsored, educational inequality that is inherent in the class of laws that stigmatizes or prohibits the teaching of LGBTQI relationships in public schools. ${ }^{171}$

\section{Student-Centered, Federal Constitutional Challenges to State Legislation That Stigmatizes or Prohibits the TEACHING OF LGBTQI RELATIONSHIPS IN PUBLIC SCHOOLS: A NECESSARY COURSE OF ACTION}

A solution is needed to adequately and legally remediate the extensive damages that result from the maintenance and implementation of these nine states' curricular laws that stigmatize or prohibit the teaching of LGBTQI relationships. ${ }^{172}$ Although legislative amendment, exercise of statutory opt-out provisions, and the Supreme Court's invalidation of same-sex marriage bans could arguably work towards easing the harms of the curricular "no promo homo" laws, these alternative avenues of reform ultimately do not cure the full extent of the injuries inflicted by these statutes upon students who are children in LGBTQI families. ${ }^{173}$ Consequently, student-centered, federal constitutional lawsuits, alleging equal protection violations under the Fourteenth Amendment, are the necessary course of action to properly challenge and nullify these discriminatory and injurious state statutes. ${ }^{174}$

170 This even includes the one federal circuit court decision that ultimately upheld the state marriage bans under consideration via an application of rational basis review and that was subsequently reversed by the Supreme Court. See DeBoer v. Snyder, 772 F.3d 388, 405 (6th Cir. 2014), rev'd sub nom. Obergefell v. Hodges, 135 S. Ct. 2584 (2015) (“And gay couples, no less than straight couples, are capable of raising children and providing stable families for them.”).

${ }^{171}$ See Latta v. Otter, 771 F.3d 456, 474 (9th Cir. 2014) (“Classifying some families, and especially their children, as of lesser value should be repugnant to all those in this nation who profess to believe in "family values.").

172 See supra Part III (discussing the full extent of the harm engendered by the state legislation that stigmatizes or prohibits the teaching of LGBTQI relationships in public schools).

173 See infra Part IV.A.

${ }^{174}$ See Udi Sommer et al., Institutional Paths to Policy Change: Judicial Versus Nonjudicial Repeal of Sodomy Laws, 47 L. \& SoC'Y REV. 409, 412 (2013) (discussing the "declaratory [and educational] value" of "a court decision" as a way to "provide[] members of [a] minority group with venues to claim redress"). 


\section{A. The Lack of Alternative Options to Adequately Remediate the Harm of State Legislation That Stigmatizes or Prohibits the Teaching of LGBTQI Relationships in Public Schools}

The best resolution regarding the existence of these "no promo homo" curricular laws in the nine states of Alabama, Texas, Mississippi, Oklahoma, South Carolina, Arizona, Utah, Louisiana, and North Carolina, as well as in local school boards that retain these types of curricular policies, would be their repeal and amendment by the self-initiation of state legislative bodies. ${ }^{175}$ This type of legislative action would be reflective of the deliberative democracy ideal advocated by Professor Cass Sunstein. ${ }^{176}$ Repeal in and of itself would be a first step to recognize that states should not discriminate in their educational curricula against students within nonheterosexual families. ${ }^{177}$ However, beyond just repeal, statutory amendment to reflect more inclusive curricula for these states would certainly be a more expansive resolution of the legal harm that has been inflicted upon students, families, and school communities by these "no promo homo" laws. ${ }^{178}$

California's current statutory educational provisions in the context of sexual education could be used as a model for this type of antidiscriminatory approach in other states' public schools. ${ }^{179}$ Even prior to the 2011 enactment of the FAIR Education Act, which made a number of inclusive, general curricular amendments to the California Education Code, ${ }^{180}$ California

175 See Cass R. Sunstein, Incompletely Theorized Agreements, 108 HARV. L. REV. 1733,1752 (1995) (arguing that "[1] egislatures are in a much better position" to invalidate or change "rules that are aspects of complex systems").

176 See Cass R. Sunstein, One CASE AT a Time: Judicial Minimalism on the SUPREME COURT 5 (1999) (asserting that it is a positive democracy-promoting outcome to have accountable actors determine political decisions after public deliberation and subsequently explain their rationales for these decisions).

${ }^{177}$ See Sommer et al., supra note 174, at 412 (noting as an analogue to the "no promo homo" curricular laws that although repeal of sodomy laws does not extinguish discrimination against sexual minorities, it does provide some context for understanding LGBT rights and it "is still a meaningful policy choice").

${ }^{178}$ See Rebecca Adams \& James Persinger, School Support and Same-Sex Parents, 42 COMMUNiQué (NAT'L ASS'N SCH. PSYChOlOGISTS) 1, 11 (2013), http://www.nasp online.org/publications/cq/42/2/school-support.aspx [http://perma.cc/3TU3-LV6R] ("In response to changing families, school districts should strive to create inclusive atmospheres, where students from all different backgrounds are respected and feel safe, yet LGBT families are typically not represented in curriculum, and biased language is often tolerated, or worse, used by staff.").

${ }^{179}$ See Madelyn Rodriguez, See No Evil, Hear No Evil, Speak No Evil; Stemming the Tide of No Promo Homo Laws in American Schools, 8 MoD. AM. 29, 31 (2013) (using California's "LGBT inclusive curriculum" as an example of the state's leadership "in understanding the importance of acknowledging the LGBT community in schools").

${ }^{180}$ See California FAIR Education Act, CAL. EDUC. CODE $\S 51204.5$ (West Supp. 2015) (providing for more inclusive social science instruction); id. $\S 51500$ ("A teacher shall not give instruction and a school district shall not sponsor any activity that promotes a 
required the following inclusive instruction as part of its comprehensive sex education program if a school district elected to offer such a program ${ }^{181}$ : "Instruction and materials shall be appropriate for use with pupils of all races, genders, sexual orientations, ethnic and cultural backgrounds, and pupils with disabilities."182 Further, this instruction "shall encourage [students] to communicate with [their] parents or guardians about human sexuality." ${ }^{183}$ In California, parents and guardians do have "the right to excuse their child from all or part of comprehensive sexual health education, HIV/AIDS prevention education, and assessments related to that education." 184 Amending the extant, discriminatory "no promo homo" laws in the nine states that still retain them to reflect this type of inclusive model of instruction, with a retention of an optout provision, would be a significant step in remediating the harm that has been perpetuated against LGBTQI family members pursuant to the current statutes. ${ }^{185}$

Although legislative action would be the optimal solution to the problems imposed by the current state legislation that stigmatizes or prohibits the teaching of LGBTQI relationships in public schools, this type of legislative

discriminatory bias on the basis of race or ethnicity, gender, religion, disability, nationality, or sexual orientation ...."); id. $\S 51501$ ("The state board and any governing board shall not adopt any textbooks or other instructional materials for use in the public schools that contain any matter reflecting adversely upon persons on the basis of race or ethnicity, gender, religion, disability, nationality, or sexual orientation ....”); id. § 60040(b) (West 2012) ("When adopting instructional materials for use in the schools, governing boards shall include only instructional materials which, in their determination, accurately portray the cultural and racial diversity of our society, including: [t]he role and contributions of ... lesbian, gay, bisexual, and transgender Americans ...."); id. § 60044(a) ("A governing board shall not adopt any instructional materials for use in the schools that, in its determination, contain: Any matter reflecting adversely upon persons on the basis of race or ethnicity, gender, religion, disability, nationality, or sexual orientation, occupation ....”). The California FAIR Education Act was a controversial legislative initiative. See, e.g., Steven G. Calabresi \& Abe Salander, Religion and the Equal Protection Clause: Why the Constitution Requires School Vouchers, 65 FLA. L. REV. 909, 1048 (2013) ("California recently enacted the California Fair Education Act which mandates that educators, textbooks, and instructional materials positively promote 'lesbian, gay, bisexual, and transgender Americans' as role models. Needless to say, this produced a strong backlash from religious groups opposed to these lifestyles." (footnote omitted) (quoting CAL. EDUC. CODE $\S 51204.5)$ ).

181 See CAL. EDUC. CODE $\S 51933$ (a) (West 2006) (discussing the requirements for state public schools that opt to provide instruction in comprehensive sexual education for their students).

182 Id. § 51933(b)(4).

${ }^{183}$ Id. $\$ 51933(\mathrm{~b})(6)$.

184 Id. $\S 51938$.

185 See, e.g., Adams \& Persinger, supra note 178, at 11 ("Learning about diversity can decrease prejudice and prepare children to live in a multicultural society. It can reduce stereotyping and misconceptions, and can help others develop a more accepting viewpoint. While the primary fear of LGBT parents is that their children will be bullied in school, their second concern is a lack of an inclusive curriculum ...."). 
action is not a likely recourse for remedy in these states. ${ }^{186}$ When legislative amendments have been offered in the past to eliminate the discriminatory language in these statutes, these efforts have been defeated. ${ }^{187}$ Further, many of these state legislative bodies have proved intransigent in repealing criminal sodomy laws invalidated by Lawrence, ${ }^{188}$ which has contributed to a generally hostile environment for acknowledgement of LGBTQI rights in any context. ${ }^{189}$ Finally, many of these states have been the situses of some of the most virulent resistance to the acknowledgment of any marriage except for that between a man and a woman, ${ }^{190}$ even after the Supreme Court's determination that same-sex marriage bans are unconstitutional in Obergefell. ${ }^{191}$ In essence, Professor Sunstein's ideal of deliberative democracy cannot be effectuated in these states given their past and current political climates as they lack "deliberative democracy['s] premium [that] is also placed on the exchange of reasons by people with different information and diverse perspectives." 192 Consequently, given this significant resistance by these nine states' legislatures to include within their codes any type of inclusive language for LGBTQI individuals, it seems unlikely that legislative action is a viable

186 See Donald J. Boudreaux \& A. C. Pritchard, The Price of Prohibition, 36 ARIZ. L. REV. 1, 9 (1994) (discussing the costs of repealing statutes).

187 See, e.g., supra text accompanying note 58.

188 See, e.g., supra text accompanying note 72.

${ }^{189}$ See Boucai, supra note 28, at 474-75 (discussing how "opponents of gay rights" situate "homosexuality's location in the realm of moral choice [to] justif[y] its prohibition and intolerance across the board: criminalization of homosexual conduct; public and private discrimination against [LGBTQI individuals]; free speech infringements; disregard or condemnation of homosexuality in public health education, including adolescent sex education; and refusal to recognize or protect same-sex relationships").

${ }^{190}$ See S.B. 2, 2015 Gen. Assemb., Reg. Sess. (N.C. 2015) (enacting into law, over gubernatorial objection, the right for public officials to recuse themselves from performing legal marriages or issuing lawful marriage licenses "based upon any sincerely held religious objection"); Richard Fausset \& Alan Blinder, States Renew Fight to Stop Same-Sex Marriage, N.Y. TIMES (Jan. 28, 2015), http://www.nytimes.com/2015/01/29/ Complainantbattles-over-same-sex-marriage-roil-statehouses-ahead-of-supreme-courtsdecision.html?_r=0 [http://perma.cc/3XXY-5Q9R] (listing proposed bills in Oklahoma, South Carolina, Texas, Utah, and North Carolina that would either bar state employees from issuing marriage licenses to same-sex couples or provide an opt-out for such officials based on a religious belief).

${ }^{191}$ See, e.g., Chuck Lindell, Texas AG: County Clerks Can Refuse Gay Couples, STATESMAN (June 28, 2015), http://www.statesman.com/news/news/texas-ag-county-clerkscan-refuse-gay-couples/nmnRZ/?ref=cbTopWidget [http://perma.cc/8Gh9-6R9T] (describing how, after the Obergefell decision by the Supreme Court, Texas Attorney General Ken Paxton instructed state employees that "county clerks can refuse to issue marriage licenses to same-sex couples based on religious objections to gay marriage" and that "judges and justices of the peace can also refuse to perform same-sex marriages"); Yuhas \& Dart, supra note 23 (describing efforts in Louisiana and Mississippi to block the issuance of marriage licenses to same-sex couples after the Obergefell decision).

192 SUNSTEIN, supra note 176, at 24-25. 
legal option to adequately cure the harm of these states' violative curricular laws.

Another potential avenue of recourse for remediating the harm that results from the maintenance and implementation of these discriminatory educational laws would be the exercise by LGBTQI parents of statutory opt-out or opt-in provisions for their children to the instruction that discriminates against their families. ${ }^{193}$ Unlike other areas of education, the sex and comprehensive health education areas have been deemed a "special case" that has motivated legislatures to allow parents to withdraw their children from such instruction. ${ }^{194}$ Under all of the legislative schemes related to the delivery of sexual or comprehensive health education instruction that stigmatizes or prohibits the teaching of LGBTQI relationships, there is a related opt-in or opt-out provision that allows parents or guardians to remove their children from this instruction. ${ }^{195}$ Mississippi, Utah, Louisiana, and North Carolina require no justification for the exercise of these parental rights. ${ }^{196}$ South Carolina broadly allows parents to opt out of this type of instruction if it "conflicts with the family's beliefs." 197 Texas allows statutory opt-out premised upon a "conflict with religious or moral beliefs." 198 Oklahoma and Arizona feature opt-out provisions based on objections to instruction that "questions beliefs or practices in sex, morality or religion."199 Alabama's statutory opt-out provision for public school curriculum is the most narrow, requiring a parental affirmation that the instruction "conflict[s] with the religious teachings of his church." 200

In accordance with this latter grouping of statutory opt-out provisions that are premised upon conflicts with religious or moral beliefs, the vast majority of scholarship that has examined the propriety or applicability of these statutes has focused upon the utilization of these statutes by families who oppose

193 See AM. Civil LiBerties UniON OF WIS. FOUND., QUESTIONS FOR PARENTS TO ASK About SEX EDUCATION AT THEIR LOCAL SCHOOL, http://www.aclu-wi.org/sites/default/ files/resources/documents/ParentQuestions_SexEd.pdf [http://perma.cc/7B62-HEF6] (listing a variety of potential sex education related questions with subjects that include both assurances that students with LGBT family members will have access to classes that "are safe and non-discriminatory" and opt-out policies for sex education classes).

194 See Kenneth L. Karst, Law, Cultural Conflict, and the Socialization of Children, 91 CALIF. L. REV. 967, 996 n.122 (2003) (discussing the "special case" of the availability of statutory parental opt-out and opt-in provisions in the context of sex education and comprehensive health education).

195 See supra text accompanying notes 55-134.

196 See supra text accompanying notes 77, 119-20, 125, 134.

197 S.C. CODE ANN. § 59-32-50 (2004).

198 TEX. EDUC. CODE ANN. § 26.010(a) (West 2012).

199 Ariz. Rev. Stat. AnN. § 15-102(A)(3) (2014); OKla. Stat. AnN. tit. 25, $\S 2003(\mathrm{~A})(3)$ (West Supp. 2015).

200 ALA. CODE $§ 16-41-6$ (2012). 
LGBTQI inclusive content on religious grounds. ${ }^{201}$ Yet, all of these statutory opt-in or opt-out provisions could arguably be utilized by LGBTQI parents who oppose the sex education or comprehensive health education instruction based on its discriminatory content towards LGBTQI individuals and families. ${ }^{202}$ Even the narrowest opt-out provision in Alabama that requires a "conflict with the religious teachings of [the parent or guardian's] church"203 would not foreclose a LGBTQI parent or guardian from exercising this right, as not all religious organizations teach exclusion of nonheterosexual relationships. ${ }^{204}$

Even though the exercise of these statutory opt-in or opt-out provisions could potentially allow LGBTQI parents of schoolchildren the ability to remove or shield their individual children from sex or health education classes that require stigmatizing or prohibitive content for nonheterosexual relationships, this option does not adequately cure the harm that these "no promo homo" statutes inflict upon the students of LGBTQI families or upon the broader school community. ${ }^{205}$ First, some of these opt-out provisions that require the exercise of the statutory right to be based upon an affirmation

${ }^{201}$ See, e.g., Eskridge, supra note 7, at 1360 (describing these opt-out provisions as being "grounded on common law or substantive due process recognition of parental rights to manage their children's upbringing and even education and allow homophobic or sexnegative parents to shield their children from information they feel would be corrupting"); Karst, supra note 194, at 997 (contextualizing statutory opt-out and opt-in provisions for sex education curriculum as being responsive to parents and guardians who are concerned about instruction that contains "tolerance of homosexual orientation"); Kevin Rogers \& Richard Fossey, Same-Sex Marriage and the Public School Curriculum: Can Parents Opt Their Children Out of Curricular Discussions About Sexual Orientation and Same-Sex Marriage?, 2011 BYU EDUC. \& L.J. 423, 464-65 (discussing the importance of either parental opt-out or opt-in statutes regarding sex education instruction for those "families who are opposed to same-sex marriage on religious ground [and who] deserve the right to protect their children from portrayals of sexuality and marriage that offend their religious values").

202 See Noa Ben-Asher, The Lawmaking Family, 90 WASH. U. L. REV. 363, 400 (2012) ("Families are vested with broad discretion in matters of education and can opt out of the public school curriculum for many reasons."); Merle H. Weiner, Dirty Words in the Classroom: Teaching the Limits of the First Amendment, 66 TENN. L. REV. 597, 671-72 (1999) (discussing how the absence of content within a curriculum can also justify statutory parental/guardian opt-out provisions).

203 ALA. CODE $§ 16-41-6$.

${ }^{204}$ See Linda C. McClain, Deliberative Democracy, Overlapping Consensus, and Same-Sex Marriage, 66 FordHAM L. REV. 1241, 1247 n.30 (1998) (noting that some religions are accommodating and supportive of LGBTQI relationships).

205 See Jennifer S. Hendricks \& Dawn Marie Howerton, Teaching Values, Teaching Stereotypes: Sex Education and Indoctrination in Public Schools, 13 U. PA. J. ConsT. L. 587, 639 (2011) ("There would be an appealing parity in allowing parents who object to opt out of the stereotypes, just as other parents are allowed to opt out of comprehensive classes. A right to opt out could be useful in raising awareness of the problem and leading to change through democratic processes. An opt-out right, however, would not be an appropriate remedy for the endorsement of sex stereotypes in the classroom."). 
regarding a conflict with religious beliefs are discriminatory in and of themselves, as they may not extend to all LGBTQI parents. ${ }^{206}$ Additionally, these opt-out and opt-in provisions are reflective of a paternalistic approach to educational rights, which situates the power to access or not to access instructional information with the parent or guardian and ignores the autonomy of the children. ${ }^{207}$ This becomes especially problematic when there is division among the family as to the propriety of an opt-out from such instruction. ${ }^{208}$ Further, the exercise of a single opt-out by an LGBTQI family still allows the discriminatory content to be disseminated to the child's peers and subsequently exposed to that child outside of the classroom, which certainly does not provide an adequate recourse to the impositions that these statutes present for school curricula. ${ }^{209}$

Additionally, despite statutory assurances that a student will not be penalized for opting out of such instruction, ${ }^{210}$ there is the same type of significant exclusionary impact that has been examined in Establishment Clause school cases that results from the exercise of such an opt-out in a sex or health education curriculum context. ${ }^{211}$ Essentially, by opting out, the children of LGBTQI families are excluded from their peer group, as well as from their access to public education instruction. ${ }^{212}$ This has the potential to demarcate such students and families with "outsider status," akin to that status that has

206 Indeed, these types of opt-out provisions could be the subject of their own constitutional challenge. See Christopher L. EISGRUBer \& LAWrence G. SAGer, RELIGIOUS FREEDOM AND THE CONSTITUTION 220 (2007) (framing opt-out provisions in the educational context as being "permissible so long as they serve legitimate public interests and do not discriminate against religion or among religions").

${ }^{207}$ See Ben-Asher, supra note 202, at 407 (arguing that the "liberty to opt out should be conditioned on alignment between the student and his or her family" and that in "cases of individual dissent, the student's autonomy (auto-nomy, literally self-legislating) should prevail"); Hendricks \& Howerton, supra note 205, at 640 (arguing that opt-out rights "inappropriately locate the right in the parent rather than the child").

208 See James G. Dwyer, The Children We Abandon: Religious Exemptions to Child Welfare and Education Laws as Denials of Equal Protection to Children of Religious Objectors, 74 N.C. L. REV. 1321, 1326 (1996) (discussing how “children's welfare interests may conflict with the preferences of parents" in the context of educational opt-out provisions).

${ }^{209}$ See Michael A. Rebell \& Robert L. Hughes, Schools, Communities, and the Courts: A Dialogic Approach to Education Reform, 14 YAlE L. \& PoL'Y REV. 99, 146 n.192 (1996) (noting how opting out of instruction does not truly curb exposure of students in public schools to the curricular content that is objectionable to the opting-out family).

210 See, e.g., S.C. CODE ANN. § 59-32-50 (2004) (charging school districts with the responsibility to not "penalize" or "embarrass" exempted students).

211 See Michael deHaven Newsom, Common School Religion: Judicial Narratives in a Protestant Empire, 11 S. CAL. INTERDISC. L.J. 219, 284 (2002) (stating that opt-out policies are not an adequate remedy in Establishment Clause school cases).

212 See id. (discussing the exclusionary impact that results from the exercise of opt-out policies in Establishment Clause school cases). 
been the focal point of many of the First Amendment educational cases.213 Such an exclusionary impact runs contrary to the important goal of inclusion in creating a safe school environment, ${ }^{214}$ with understanding of familial differences by students, staff, and administrators. ${ }^{215}$ As a corollary to the exclusionary impact that would likely result from LGBTQI parents opting their children out of discriminatory sex education, this individual action will not likely effectuate a collective exercise of such a right, thereby enabling continued instruction in this discriminatory fashion. ${ }^{216}$

Another concern and harm that could result from the exercise of these types of statutory opt-out provisions is pedagogical - the fragmentation of curriculum and programming within the school itself. ${ }^{217}$ Finally, as a purely pragmatic concern, LGBTQI families who are considering opting out of this type of stigmatizing or prohibitive instruction may face a financial burden that other schoolchildren's families do not-the "fund[ing] [of] their own alternative arrangements"-in order to ensure complete access to the educational content that they will miss. ${ }^{218}$ Consequently, for all of these reasons, it is clear that the exercise of statutory opt-out or opt-in provisions by LGBTQI parents in order to ensure that their children are not subject to discriminatory content in the public school curriculum is not a sufficient

213 See, e.g., Hendricks \& Howerton, supra note 205, at 639-40 (providing that opt-out provisions in sex education, when exercised in opposition to sex stereotypes that are taught pursuant to this curriculum, "suggest that opposition to sex stereotypes is an idiosyncratic personal belief rather than a constitutional value"); Lisa Shaw Roy, The Establishment Clause and the Concept of Inclusion, 83 OR. L. REV. 1, 20 (2004) ("[T]he Establishment Clause is largely about protecting the feelings of the nonadherent from a public manifestation that may confer outsider status.").

214 See Ari Ezra Waldman, Tormented: Antigay Bullying in Schools, 84 TEMP. L. REV. 385, 438 (2012) (hypothesizing that "policies that integrate gays into the school community and provide them with social support [including inclusion of sexual orientation in health education] are the most effective policies to counteract pervasive and destructive antigay harassment in schools and online").

215 See Debbie Ollis, Planning and Delivering Interventions to Promote Gender and Sexuality, in BULlyING: EXPERIENCES AND DISCOURSES OF SEXUALITY AND GENDER 145, 154 (Ian Rivers \& Neil Duncan eds., 2013) (stating that inclusive content in curriculum regarding sexuality for young people "has been shown to increase a sense of professionalism and theoretical understanding" among teachers).

216 See Lauren E. Willis, When Nudges Fail: Slippery Defaults, 80 U. CHI. L. REV. $1155,1204-05$ (2013) (noting that often opposing parties who exercise opt-out provisions like those within the sex education statutes "will only have access to their members and are unlikely to influence the opt-out decisions of others").

217 See Rosemary C. Salomone, Common Schools, Uncommon Values: Listening to the Voices of Dissent, 14 YALE L. \& POL'Y REV. 169, 213 (1996) ("If schools were to permit parents the absolute right to opt out of certain classes or programs, they may run the risk of fragmenting the curriculum and sacrificing the cohesiveness that a sound educational program, integrated across subject areas, should strive to attain.”).

218 See REX AHDAR \& IAN LeIGH, RELIGIOUS FrEEDOM IN THE LibERAL STATE 260 (2d ed. 2013) (discussing, in an international context, how parents who exercise opt-out provisions in public schools "may have to fund their own alternative arrangements"). 
remedy for the harm that is inflicted by state legislation that stigmatizes or prohibits the teaching of LGBTQI relationships in public schools.

Because the legislation at issue is not (and has almost no potential to be amended to be) demonstrative of deliberative democracy, ${ }^{219}$ and because no other complete, viable statutory remedies for the harm of these state statutes exist, ${ }^{220}$ a judicial remedy is necessary. Arguably, the Supreme Court's holding in the 2015 Obergefell case, that same-sex marriage bans are unconstitutional and that states must recognize lawful same-sex marriages performed in other states, ${ }^{221}$ could potentially cure some of the harms of the state statutes that stigmatize or prohibit the teaching of LGBTQI relationships in public schools. ${ }^{22}$ Yet, such federal court action regarding marriage equality will not, on its own, cure the damages inflicted by these discriminatory curricular laws.

Many of the federal courts that have struck down discriminatory statutes regarding LGBTQI relationships in the context of marriage have focused upon the impact of this discrimination on children of LGBTQI parents. ${ }^{223}$ Notably, the Supreme Court utilized this type of rationale in finding the federal Defense of Marriage Act (DOMA), which defined "'marriage' [to] mean[] only a legal union between one man and one woman as husband and wife, and the word 'spouse' [to] refer[] only to a person of the opposite sex who is a husband or

219 See SUNSTEIN, supra note 176, at 25 ("Nor can legislation be justified on grounds that deny the fundamental equality of human beings, or that reflect contempt for fellow citizens, or that attempt to humiliate them. These ideas are part of a liberal conception of political legitimacy; they embody an ideal of reciprocity .....").

220 See supra text accompanying notes $175-218$.

${ }^{221}$ See Obergefell v. Hodges, 135 S. Ct. 2584, 2605-06, 2608 (2015) (holding that under the Due Process and Equal Protection Clauses of the Fourteenth Amendment, "samesex couples may exercise the fundamental right to marry," invalidating state laws that "exclude same-sex couples from civil marriage" that is available to "opposite-sex couples," and holding "that there is no lawful basis for a State to refuse to recognize a lawful samesex marriage performed in another State on the ground of its same-sex character").

${ }^{222}$ See Anthony C. Infanti, The House of Windsor: Accentuating the Heteronormativity in the Tax Incentives for Procreation, 89 WASH. L. REV. 1185, 1188 (2014) (discussing how a key component of federal judicial invalidation of same-sex marriage bans "has been the effect of prohibitions against same-sex marriage on the family and, particularly, on the children of same-sex couples").

${ }^{223}$ See, e.g., Campaign for S. Equal. v. Bryant, 64 F. Supp. 3d 906, 926 (S.D. Miss. 2014) ("Although Windsor does not address State statutes and constitutional amendments banning same-sex marriage, its language leaves no room to allow homosexual citizens, and the children they love and rear, to be treated as second-class citizens."); Golinski v. U.S. Office of Pers. Mgmt., 824 F. Supp. 2d 968, 992 (N.D. Cal. 2012) ("The denial of recognition and withholding of marital benefits to same-sex couples does nothing to support opposite-sex parenting, but rather merely serves to endanger children of same-sex parents by denying them " "the immeasurable advantages that flow from the assurance of a stable family structure," when afforded equal recognition ...."” (quoting Gill v. Office of Pers. Mgmt., 699 F. Supp. 2d 374, 389 (D. Mass 2010))). 
wife," 224 to be violative of the Fifth Amendment's Due Process Clause in United States $v$. Windsor. ${ }^{225}$ Justice Kennedy emphasized the negative consequences of DOMA's discriminatory impact on the children of same-sex couples with constitutional privacy rights granted by Lawrence:

DOMA forces same-sex couples to live as married for the purpose of state law but unmarried for the purpose of federal law, thus diminishing the stability and predictability of basic personal relations the State has found it proper to acknowledge and protect. By this dynamic DOMA undermines both the public and private significance of state-sanctioned same-sex marriages; for it tells those couples, and all the world, that their otherwise valid marriages are unworthy of federal recognition. This places same-sex couples in an unstable position of being in a second-tier marriage. The differentiation demeans the couple, whose moral and sexual choices the Constitution protects, and whose relationship the State has sought to dignify. And it humiliates tens of thousands of children now being raised by same-sex couples. The law in question makes it even more difficult for the children to understand the integrity and closeness of their own family and its concord with other families in their community and in their daily lives. ${ }^{226}$

Similarly, many of the federal courts, including the Supreme Court, that have found state marriage bans to be unconstitutional violations of the Due Process or Equal Protection Clauses have referenced the harm that children of same-sex couples endure as a consequence of these bans.227 One of the Supreme Court's primary focal points in finding a fundamental right to marriage for same-sex couples in Obergefell $v$. Hodges was the devastating impact that state marriage bans had upon the children of these families:

Excluding same-sex couples from marriage thus conflicts with a central premise of the right to marry. Without the recognition, stability, and predictability marriage offers, their children suffer the stigma of knowing their families are somehow lesser. They also suffer the significant material

${ }^{224}$ Defense of Marriage Act, 1 U.S.C. $\$ 7$ (2012), invalidated by United States v. Windsor, 133 S. Ct. 2675 (2013).

225 Windsor, 133 S. Ct. at 2695-96.

${ }^{226}$ Id. at 2694 (citation omitted) (citing Lawrence v. Texas, 539 U.S. 558 (2003)).

227 See, e.g., Baskin v. Bogan, 766 F.3d 648, 658 (7th Cir.), cert. denied, 135 S. Ct. 316, and cert. denied sub nom. Walker v. Wolf, 135 S. Ct. 316 (2014) ("The harm to homosexuals (and ... to their adopted children) of being denied the right to marry is considerable."); Kitchen v. Herbert, 755 F.3d 1193, 1226 (10th Cir. 2014), cert. denied, 135 S. Ct. 265 (2014) ("Windsor thus indicates that same-sex marriage restrictions communicate to children the message that same-sex parents are less deserving of family recognition than other parents. ... Amendment 3, like DOMA, conveys a harmful message to the children of same-sex couples."); De Leon v. Perry, 975 F. Supp. 2d 632, 653 (W.D. Tex. 2014), aff'd sub nom. De Leon v. Abbott, 791 F.3d 619 (5th Cir. 2015) ("To the contrary, this Court finds that far from encouraging a stable environment for childrearing, Section 32 denies children of same-sex parents the protections and stability they would enjoy if their parents could marry."). 
costs of being raised by unmarried parents, relegated through no fault of their own to a more difficult and uncertain family life. The marriage laws at issue here thus harm and humiliate the children of same-sex couples. 228

Even the Sixth Circuit, which ultimately upheld the constitutionality of these types of state marriage bans and which was reversed by the Supreme Court in Obergefell, recognized that these bans "affect not only gay couples but also their children." 229 The courts' focus on stigmatization of LGBTQI families and the states' creation of a perception of those families being secondclass families has particular resonance for the harm that flows from the continued existence of state, curricular "no promo homo" laws. ${ }^{230}$ Certainly, these types of educational laws that stigmatize or prohibit the teaching of LGBTQI relationships in public schools, akin to state marriage bans, "detract[] from [the states'] goal[s] of promoting optimal environments for children."231

Given the parity between the state LGBTQI marriage bans and the "no promo homo" curricular laws, ${ }^{232}$ one could argue that the positive resolutions of the majority of these cases, alongside the finding by the Supreme Court in Obergefell that such bans are unconstitutional, ${ }^{233}$ in terms of inclusiveness, equal protection, and due process, alleviate the harm of the curricular laws. The Obergefell decision expressly provides that "[b]y giving recognition and legal structure to their parents' relationship, marriage allows children 'to understand the integrity and closeness of their own family and its concord with other families in their community and in their daily lives." "234 This type of legal recognition could have similar resonance in educational settings for all public school children.

However, while it is a positive step towards protecting parent-child relationships, marriage equality, in and of itself, does not cure all of the

${ }^{228}$ Obergefell v. Hodges, 135 S. Ct. 2584, 2600-01 (2015).

${ }^{229}$ DeBoer v. Snyder, 772 F.3d 388, 408 (6th Cir. 2014), rev'd sub nom. Obergefell, 135 S. Ct. 2584.

${ }^{230}$ See Latta v. Otter, 771 F.3d 456, 474 (9th Cir. 2014) ("To allow same-sex couples to adopt children and then to label their families as second-class because the adoptive parents are of the same sex is cruel as well as unconstitutional."); Geiger v. Kitzhaber, 994 F. Supp. 2d 1128, 1144 (D. Or. 2014) ("Creating second-tier families does not advance the state's strong interest in promoting and protecting all families."); De Leon, 975 F. Supp. 2d at 653 ("Instead, Section 32 causes needless stigmatization and humiliation for children being raised by the loving same-sex couples being targeted.").

231 Searcy v. Strange, No. 14-0208-CG-N, 2015 WL 328728, at *5 (S.D. Ala. Jan. 23, 2015) ("[T]hese laws further injures [sic] those children of all couples who are themselves gay or lesbian, and who will grow up knowing that Alabama does not believe they are as capable of creating a family as their heterosexual friends.").

232 See Obergefell, 135 S. Ct. at 2590 (finding that "the right to marry . . . safeguards children and families and thus draws meaning from related rights of childrearing, procreation, and education" (emphasis added) (citing the seminal cases of Pierce v. Society of Sisters, 268 U.S. 510 (1925), and Meyer v. Nebraska, 262 U.S. 390 (1923))).

233 See id. at 2605-06.

${ }^{234}$ Id. at 2600 (quoting United States v. Windsor, 133 S. Ct. 2675, 2694 (2013)). 
discrimination faced by LGBTQI families. ${ }^{235}$ Further, the Supreme Court's recognition of marriage equality does not extend to protect all children of LGBTQI families; not all of these children have parents who are married or who want to be married based on claims regarding the heteronormativity of marriage or for other reasons. ${ }^{236}$ Finally, the Supreme Court's holding in Obergefell will not likely deter the states that still retain discriminatory curricular laws regarding familial relationships from continuing to require such teaching in their public schools, given their past, general intransigence in properly conveying Lawrence's effect on state sodomy laws and how they are taught in schools. ${ }^{237}$ For many of these states, it took years to remove these curricular laws' mandates that nonheterosexual relationships were criminal; 238 this still remains part of Alabama's and Texas's "no promo homo" laws for its public schools. ${ }^{239}$ Directly after the Obergefell ruling, several of these states "indicated that they would resist the ruling with delay, bureaucratic niggling and circumvention of the verdict on religious grounds." 240 Specifically, Texas, Louisiana, and Mississippi all attempted to block the issuance of same-sex marriage licenses after the Supreme Court's decision. ${ }^{241}$ When states show such visible resistance to the Supreme Court's invalidation of same-sex marriage bans, it stands to reason that those states will also demonstrate equivalent, if not heightened, resistance in educating their schoolchildren on the legality and propriety of LGBTQI relationships. Consequently, federal court decisions, including the Supreme Court's Obergefell decision, that

235 See, e.g., Rebecca Aviel, A New Formalism for Family Law, 55 WM. \& MARY L. REV. 2003, 2062 n.272 (2014) (arguing that, although an important step, "universal recognition of marriage rights for same-sex couples" does not provide an exclusive and allcomprehensive remedy to the "tangible and unjustifiable harms" endured by "children of same-sex couples... from the unequal treatment their parents receive under traditional marriage laws").

${ }^{236}$ See Gwendolyn M. Leachman, From Protest to Perry: How Litigation Shaped the LGBT Movement's Agenda, 47 U.C. DAVIS L. REV. 1667, 1676 (2014) ("Instead of attempting to undermine the monogamous, heterosexual pairings institutionalized through the legal definition of marriage, LGBT litigators and queer protestors alike have rallied behind a cause that many argue alienates alternative sexual relationships and family structures." (footnote omitted) (citing Ellen Willis, Can Marriage Be Saved: A Forum, NATION, July 5, 2004, at 16)).

237 See, e.g., supra text accompanying note 68.

238 See, e.g., supra text accompanying notes 131-32.

${ }^{239}$ See ALA. CODE $\S 16-40 A-2(c)(8)$ (2012) (providing that sexual education and sexually transmitted diseases materials and instruction "should include ... [a]n emphasis, in a factual manner and from a public health perspective, that homosexuality is not a lifestyle acceptable to the general public and that homosexual conduct is a criminal offense under the laws of the state"); TeX. Health \& SAFEty COdE ANN. § 85.007(b)(2) (West 2010) ("The materials in the education programs intended for persons younger than 18 years of age must ... state that homosexual conduct is not an acceptable lifestyle and is a criminal offense under Section 21.06, Penal Code.").

240 Yuhas \& Dart, supra note 23.

${ }^{241}$ See supra note 191. 
invalidate state same-sex marriage bans do not suffice on their own to sufficiently cure the injuries that are perpetuated by state legislation that stigmatizes or prohibits the teaching of LGBTQI relationships in public schools.

Because there are no other viable solutions to remediate this harm, independent federal litigation is necessary to invalidate these discriminatory and injurious state curricular laws. "People rely on the finality of judicial decisions." 242 In this instance, finality is an imperative goal in terms of ending state-mandated, curricular discrimination against children of LGBTQI families in public schools. This finality and wholeness in terms of remediation of harm can be achieved through student-centered, federal constitutional lawsuits that challenge the remaining state laws that stigmatize or prohibit the teaching of LGBTQI relationships in public schools.

\section{B. The Viability of Student-Centered, Federal Constitutional Lawsuits to Adequately Remediate the Harm of State Legislation That Stigmatizes or Prohibits the Teaching of LGBTQI Relationships in Public Schools}

Children of LGBTQI families should initiate federal constitutional lawsuits that challenge the state legislation that stigmatizes or prohibits the teaching of LGBTQI relationships in public schools as being violative of the Fourteenth Amendment Equal Protection Clause. Although the student children have a strong likelihood of prevailing on their claims under a theory of heightened scrutiny, ${ }^{243}$ these plaintiffs will still prevail if courts choose to apply the state deferential standard of rational basis review. Consequently, federal judicial invalidation of these statutes via student-centered lawsuits will be the most efficient and most effective way to finally and wholly remediate the harms of these discriminatory laws.

Specifically, students who are children of LGBTQI parents should assert that the "no promo homo" curricular laws are a violation of the Equal Protection Clause, as these children have standing for a myriad of reasons as a protected class entitled to elevated scrutiny under the Fourteenth Amendment. ${ }^{244}$ The Equal Protection Clause of the Fourteenth Amendment

242 William Michael Treanor \& Gene B. Sperling, Prospective Overruling and the Revival of "Unconstitutional” Statutes, 93 CoLuM. L. REV. 1902, 1954 (1993).

243 See Katie R. Eyer, Constitutional Crossroads and the Canon of Rational Basis Review, 48 U.C. DAVIS L. REV. 527, 571-72 (2014) (discussing how most LGB advocates have strived to obtain heightened scrutiny "protected class status for lesbians and gays" with an "increasing possibility of success").

${ }^{244}$ See, e.g., Christopher R. Leslie, Standing in the Way of Equality: How States Use Standing Doctrine to Insulate Sodomy Laws from Constitutional Attack, 2001 WIS. L. REV. 29, 93-94 ("Invoking the illegality of same-sex conduct, many school officials forbid discussions about homosexuality at all, except to teach students that homosexual activity is criminal. Having one's access to information curtailed by a government action constitutes standing injury." (footnote omitted)). 
requires that no State shall "deny to any person within its jurisdiction the equal protection of the laws." 245 This "is essentially a direction that all persons similarly situated should be treated alike." 246 Federal courts have yet to determine the level of constitutional scrutiny that applies to children of LGBTQI parents in an Equal Protection context, 247 and the amount of scholarship in this general area is incredibly limited. ${ }^{248}$ Although it could be argued that these students should not be subject to the protections of heightened scrutiny given the undetermined level of scrutiny for equal protection claims based on sexual orientation, ${ }^{249}$ the counterargument is that

245 U.S. CONST. amend. XIV, $\S 1$.

246 City of Cleburne v. Cleburne Living Ctr., 473 U.S. 432, 439 (1985) (citing Plyler v. Doe, 457 U.S. 202, 216 (1982)).

${ }^{247}$ See Catherine E. Smith, Equal Protection for Children of Same-Sex Parents, 90 WASH. U. L. REV. 1589, 1591 (2013) ("To date, no state or federal court has directly addressed what level of scrutiny applies to children who face discrimination because of their same-sex parents' relationships.").

${ }^{248}$ Two scholars have addressed the general issue of equal protection standards for children of LGBTQI parents as the focus of their theses. See id. at 1615-16 (arguing that these children who are denied a government benefit as a result of their parents' sexual orientation should be treated like illegitimate children under Equal Protection analysis and, therefore, that they are entitled to intermediate scrutiny class status); Tanya Washington, In Windsor's Wake: Section 2 of DOMA's Defense of Marriage at the Expense of Children, 48 IND. L. REV. 1, 52-53 (2014) (arguing that children of LGBTQI parents have standing to challenge section 2 of DOMA and that they should be entitled to heightened scrutiny like the class of children in Plyler v. Doe).

249 See Obergefell v. Hodges, 135 S. Ct. 2584 (2015) (making no reference to the applicable level of scrutiny for constitutional challenges based on sexual orientation); United States v. Windsor, 133 S. Ct. 2675 (2013) (same). Compare Kitchen v. Herbert, 755 F.3d 1193, 1218, 1229-30 (10th Cir. 2014), cert. denied, 135 S. Ct. 265 (2014) (applying strict scrutiny in finding a state same-sex marriage ban to be unconstitutional under the Due Process and Equal Protection Clauses), and Latta v. Otter, 771 F.3d 456, 476 (9th Cir. 2014), cert. denied, 135 S. Ct. 2931, and cert. denied sub nom. Idaho v. Latta, 135 S. Ct. 2931, and cert. dismissed sub nom. Coal. for the Prot. of Marriage v. Sevcik, 136 S. Ct. 13 (2015) (applying heightened scrutiny to declare state marriage restrictions as violative of the Equal Protection Clause as they "unjustifiably discriminate on the basis of sexual orientation"), with Campaign for S. Equal. v. Bryant, 64 F. Supp. 3d 906, 942, 954 (S.D. Miss. 2014), aff'd, 791 F.3d 625 (5th Cir. 2015) (applying rational basis review to invalidate state same-sex marriage ban), De Leon v. Perry, 975 F. Supp. 2d 632, 652 (W.D. Tex. 2014), aff'd sub nom. De Leon v. Abbott, 791 F.3d 619 (5th Cir. 2015) (finding that there is an increased likelihood that plaintiffs will ultimately prevail on their argument for heightened scrutiny but that plaintiffs prevail on their equal protection claims "even under the most deferential rational basis level of review" when invalidating a state same-sex marriage ban), and Geiger v. Kitzhaber, 994 F. Supp. 2d 1128, 1141-42 (D. Or. 2014), appeal dismissed, No. 14-35427, 2014 WL 8628611 (9th Cir. Aug. 27, 2014), cert. denied sub nom. Nat'l Org. for Marriage, Inc. v. Geiger, 135 S. Ct. 1860 (2015) (applying rational basis review to strike down an Oregon marriage ban as unconstitutional under the Fourteenth Amendment's Equal Protection Clause). 
constitutional inquiries that touch on education have special significance that can elevate the level of scrutiny. 250

Essentially, students who are children of LGBTQI parents should be entitled to heightened scrutiny protection analogous to the rationale applied in Plyler v. Doe, regardless of the Supreme Court's determination, if any, ${ }^{251}$ as to what the appropriate level of scrutiny is for laws that discriminate based upon sexual orientation. ${ }^{252}$ In Plyler, the Court determined that Texas's denial of free public education to undocumented children was a violation of the Equal Protection Clause. ${ }^{253}$ In the majority decision, Justice Brennan acknowledged that the standard application of the Equal Protection Clause to most state action is rational basis review, where the Court "seek[s] only the assurance that the classification at issue bears some fair relationship to a legitimate public purpose." 254 Yet, the Court found that the characteristics of the plaintiffs - minor children of undocumented resident aliens who "can affect neither their parents' conduct nor their own status"- entitled them as a class to elevated scrutiny. ${ }^{255}$ The Court emphasized that these children constituted a "discrete class of children not accountable for their disabling status." 256 In evaluating the state law that "impose[d] its discriminatory burden on the basis of a legal characteristic over which children can have little control," 257 the Court highlighted the primacy of education and public schools "as the primary vehicle for transmitting "the values on which our society rests." 258 Consequently, the Court allocated a heightened level of review, without providing a clear classification for it-providing that the contested state

${ }^{250}$ See Plyler, 457 U.S. at 221 (emphasizing the "supreme importance" of education to support an application of heightened scrutiny to a class of children of undocumented citizens); see also Michael Olivas, No Undocumented Child Left Behind: PlyLER $V$. DOE AND THE EDUCATION OF UNDOCUMENTED SCHOOLCHILDREN 21 (2012) (discussing how Justice Brennan's characterization of education's "fundamental role in maintaining the fabric of our society" allowed for an elevated level of scrutiny in the case (quoting Plyler, 457 U.S. at 221)).

251 See David Bernstein, Justice Kennedy's Opinion in the Gay Marriage Case May Upend Fifty-Plus Years of Settled Equal Protection and Due Process Jurisprudence, WASH. POST (June 26, 2015), http://www.washingtonpost.com/news/volokh-conspiracy/ $\mathrm{wp} / 2015 / 06 / 26 /$ justice-kennedys-opinion-in-the-gay-marriage-case-may-upend-fifty-plusyears-of-settled-equal-protection-and-due-process-jurisprudence/ [https://perma.cc/5NYUTUY5] (discussing Supreme Court case law's lack of identification of applicable tiered scrutiny classifications for cases involving discrimination based on sexual orientation).

252 Plyler, 457 U.S. at 219-21 (using the special nature of education to justify the application of elevated scrutiny to the class of undocumented immigrant children in the context of access to education, despite the traditional application of rational basis review for alienage classifications).

253 See id. at $205,230$.

254 Id. at 216.

255 Id. at 220 (quoting Trimble v. Gordon, 430 U.S. 762, 770 (1977)).

256 Id. at 223 .

257 Id. at 220.

258 Plyler, 457 U.S. at 221 (quoting Ambach v. Norwick, 441 U.S. 68, 76 (1979)). 
statute's discrimination could not be "considered rational unless it furthers some substantial goal of the State." 259 The Court determined that no substantial interest supported the law, including "the asserted state prerogative to act against undocumented children solely on the basis of their undocumented status." 260

Plyler emphasized that "[t]he Equal Protection Clause was intended to work nothing less than the abolition of all caste-based and invidious classbased legislation." 261 The Court also stressed that "[e]ven if the State found it expedient to control the conduct of adults by acting against their children, legislation directing the onus of a parent's misconduct against his children does not comport with fundamental conceptions of justice."262 These pronouncements by the Court have especial significance for a constitutional lawsuit brought by children of LGBTQI parents that challenges state laws that stigmatize or prohibit the teaching of LGBTQI relationships in public schools. Although the sexual intimacy between nonheterosexuals cannot be constitutionally penalized per Lawrence, ${ }^{263}$ unlike the unlawful immigration of the parents in Plyler, the basic rationale of providing heightened educational protections when analyzing discriminatory state laws for children of individuals the State would like to punish applies equally to students of LGBTQI parents. Because "education has a fundamental role in maintaining the fabric of our society," 264 and because "imposing disabilities on the ... child is contrary to the basic concept of our system that legal burdens should bear some relationship to individual responsibility or wrongdoing,"265 children of LGBTQI parents should also be entitled to heightened scrutiny in challenging state curricular "no promo homo" laws.

Scholars are divided on the classification of the scrutiny that was applied in Plyler, calling it intermediate scrutiny, 266 "rigorous rational basis scrutiny,"267 "meaningful review," 268 or something in between. ${ }^{269}$ Yet, all

259 Id. at 224.

${ }^{260} \mathrm{Id}$. at 227.

${ }^{261}$ Id. at 213 .

${ }^{262} \mathrm{Id}$. at 220 .

${ }^{263}$ Lawrence v. Texas, 539 U.S. 558, 564, 578-79 (2003).

264 Plyler, 457 U.S. at 221.

${ }^{265}$ Id. at 220 (quoting Weber v. Aetna Cas. \& Sur. Co., 406 U.S. 164, 175 (1972)).

${ }^{266}$ See Olivas, supra note 250, at 21 (noting that Plyler's scrutiny has been "characterized as intermediate scrutiny"); Julie A. Nice, The Emerging Third Strand in Equal Protection Jurisprudence: Recognizing the Co-Constitutive Nature of Rights and Classes, 99 U. ILL. L. REv. 1209, 1213 (1999) ("Because the Court applied something less than strict scrutiny but more than rational review, Plyler is frequently categorized as a case of intermediate scrutiny.").

${ }^{267}$ See, e.g., Miranda Oshige McGowan, Lifting the Veil on Rigorous Rational Basis Scrutiny, 96 MARQ. L. REV. 377, 382 (2012) (listing Plyler as an example of a Supreme Court case applying "rigorous rational basis scrutiny"). 
scholarship agrees that it is beyond baseline rational basis review. The political powerlessness of the children ${ }^{270}$ and the "discrimination against children based on parental conduct" 271 in these types of lawsuits and in Plyler is substantially similar and, therefore, would justify a heightened level of scrutiny-regardless of a distinct classification of that scrutiny.

Relying upon Plyler as the basis for the application of heightened scrutiny analysis, student children of LGBTQI individuals could successfully invalidate laws that stigmatize or prohibit the educational presentation of LGBTQI relationships in public schools as the discrimination of these laws does not "further[] some substantial goal of the State." 272 Parental or governmental homophobia as an asserted state goal cannot be enough to sustain an equal protection challenge to these curricular laws. ${ }^{273}$ Indeed, a heterosexual parent's substantive due process interest in controlling the upbringing of one's child should not legally be able to trump a LGBTQI parent's same interest when it results in harmful, disparate "treatment by a State between classes of individuals whose situations are arguably indistinguishable"274_all students in public schools. The historical dedication to Meyer liberty interests in raising children cannot constitutionally disfavor one group of children over the other in this way, ${ }^{275}$ as "[e]qual protection of the laws is not achieved through indiscriminate imposition of inequalities." 276 In sum, federal courts should apply heightened scrutiny to find that children of LGBTQI parents cannot be legally demarcated as having second-class status via the maintenance and

${ }^{268}$ See, e.g., Eyer, supra note 243, at 576-77 (classifying Romer, Windsor, and Plyler as "'meaningful review' cases" where the Court has applied "more than de minimis rational basis review").

${ }^{269}$ See Bertrall L. Ross II, The State As Witness: Windsor, Shelby County, and Judicial Distrust of the Legislative Record, 89 N.Y.U. L. REV. 2027, 2076 n.236 (2014) (characterizing Plyler as "applying something in between rigorous rational basis review and intermediate scrutiny").

270 See Darren Lenard Hutchinson, "Not Without Political Power": Gays and Lesbians, Equal Protection and the Suspect Class Doctrine, 65 ALA. L. REV. 975, 1014 (2014) (discussing how political powerlessness was at the center of the Plyler decision).

271 See Washington, supra note 248, at 53 (arguing that "Section 2 [of DOMA] should be subject to heightened scrutiny because it enables discrimination against children based on parental conduct").

272 Plyler v. Doe, 457 U.S. 202, 224 (1982).

273 See William N. Eskridge, Jr., Multivocal Prejudices and Homo Equity, 74 IND. L.J. 1085, 1099 (1999) (identifying "parental homophobia" as "often [being] the basis for no promo homo policies in schools").

274 Ross v. Moffitt, 417 U.S. 600, 609 (1974).

275 See, e.g., Jacob M. Victor, Note, Regulating Sexual Orientation Change Efforts: The California Approach, Its Limitations, and Potential Alternatives, 123 YALE L.J. 1532, 1561 (2014) ("Considering the strong public values that favor parents' control over their children's upbringing, these ['no promo homo'] arguments have proven quite powerful rhetorically and politically." (footnote omitted)).

276 Shelley v. Kraemer, 334 U.S. 1, 22 (1948). 
enforcement of curricular "no promo homo" laws as such harmfully discriminatory demarcation does not further a substantial state goal. ${ }^{277}$

Although there is a viable foundation for constitutional challenges to these types of education laws under a heightened scrutiny analysis, a final avenue of recourse will still be available for these claims in the case of judicial hesitance to apply elevated scrutiny to these equal protection challenges. ${ }^{278}$ In essence, these types of laws would even fail under minimal rational basis review as a state would not be able to show that this legislation "bear[s] some rational relationship to legitimate state purposes." 279 Laws cannot withstand equal protection scrutiny if they have been premised on pure unconstitutional animus. ${ }^{280}$ " $[\mathrm{I}] \mathrm{f}$ the constitutional conception of 'equal protection of the laws' means anything, it must at the very least mean that a bare ... desire to harm a politically unpopular group cannot constitute a legitimate governmental interest." 281 In the case of the nine states' curricular "no promo homo" laws, the pure animus towards LGBTQI individuals or the "desire to harm [that] politically unpopular group" cannot qualify as a constitutional legitimate governmental interest to sustain such laws' validity. This type of stigma against LGBTQI individuals is magnified as applied towards the children of those individuals. ${ }^{282}$ Therefore, these laws would not be able to withstand rational basis review, like the challenged law of Romer v. Evans. ${ }^{283}$

In Romer, the Court invalidated a state constitutional amendment that prohibited "all legislative, executive or judicial action at any level of state or

${ }^{277}$ See Helen Norton, The Equal Protection Implications of Government's Hateful Speech, 54 WM. \& MARY L. REV. 159, 200 (2012) (arguing that the "no promo homo" curricular laws "might violate the Equal Protection Clause under behavioral harm analysis if the plaintiffs could show that such speech facilitated discrimination against GLBT students by other students or faculty" or "that such government speech communicated GLBT students' outsider or second-class status in violation of the Equal Protection Clause"). The application of such analysis applies equally, if not with more force, to students of LGBTQI parents in public schools.

278 See, e.g., San Antonio Indep. Sch. Dist. v. Rodriguez, 411 U.S. 1, 40 (1973) (applying rational basis review, rather than heightened scrutiny, in evaluating a student class Equal Protection challenge).

279 Id

280 See United States v. Windsor, 133 S. Ct. 2675, 2693 (2013) (“In determining whether a law is motived by an improper animus or purpose, "[d]iscriminations of an unusual character' especially require careful consideration." (alteration in original) (quoting Romer v. Evans, 517 U.S. 620, 633 (1996))); see also Susannah W. Pollvogt, Unconstitutional Animus, 81 FORDHAM L. REV. 887, 892 (2012) (discussing the unconstitutionality of pure animus).

${ }^{281}$ U.S. Dep't of Agric. v. Moreno, 413 U.S. 528, 534 (1973).

282 See William N. Eskridge, JR., Equality Practice: Civil Unions and the FUTURE OF GAY RIGHTS 37 (2002) (positing that Romer's opening line harkening back to Justice Harlan's pronouncement in his dissent to Plessy that the Court "neither knows nor tolerates classes among its citizens" contravenes the "no promo homo ... arguments that gay people are and ought to be second-class citizens").

283 Romer, 517 U.S. at 623. 
local government designed to protect the named class ... [of] homosexual persons or gays and lesbians." 284 Specifically, it found that the state law failed the low threshold of rational basis review:

First, the amendment has the peculiar property of imposing a broad and undifferentiated disability on a single named group, an exceptional and, as we shall explain, invalid form of legislation. Second, its sheer breadth is so discontinuous with the reasons offered for it that the amendment seems inexplicable by anything but animus toward the class it affects; it lacks a rational relationship to legitimate state interests. ${ }^{285}$

Similar to Romer, the state educational laws that stigmatize or prohibit the teaching of LGBTQI relationships are based on unconstitutional animus towards families with nonheterosexual parents. ${ }^{286}$ The disparities that result from the maintenance and enforcement of these laws are "invidiously discriminatory," 287 and they will not be able to even withstand the state deferential scrutiny of rational basis review. As such, the federal judiciary would have an alternative avenue in invalidating these discriminatory, curricular laws.

Consequently, although heightened scrutiny should be the level of constitutional analysis for children of LGBTQI families' equal protection claims against legislation that stigmatizes or prohibits the teaching of LGBTQI relationships in public schools, these student plaintiffs will also be able to overcome a bar of rational basis review in future litigations. Given the increasing diversity in the demographics of the country and the heated political environment that has been generated by the states' dialogues on the meaning of family, ${ }^{288}$ it seems very likely that courts will soon be presented with these types of constitutional challenges to achieve educational equality for all families. 289

\section{CONCLUSION}

In the unanimous Brown v. Board of Education decision, the Court stressed the importance of education as "a principal instrument in awakening

284 Id. at 624.

$285 \mathrm{Id}$. at 632 .

286 See id.

287 San Antonio Indep. Sch. Dist. v. Rodriguez, 411 U.S. 1, 55 (1973).

288 See Deirdre M. Bowen, All That Heaven Will Allow: A Statistical Analysis of the Coexistence of Same-Sex Marriage and Gay Matrimonial Bans, 91 DENV. U. L. REV. 277, 281 (2014) ("The broadening definition of marriage and the evolution of family will remain in the forefront of our national, legal, political, and cultural consciousness.").

${ }^{289}$ See Catherine E. Smith \& Susannah W. Pollvogt, Children as Proto-Citizens: Equal Protection, Citizenship, and Lessons from the Child-Centered Cases, 48 U.C. DAVIS L. REV. 655, 664 (2014) (forecasting a "resurgence" of "child-centered cases" after the resolution by the Supreme Court of the constitutionality of same-sex marriage bans). 
the child to cultural values, in preparing him for later professional training, and in helping him to adjust normally to his environment." 290 The state legislation that still exists in nine states that stigmatizes or prohibits the teaching of LGBTQI relationships only serves to enforce a state orthodoxy of sex heterogamy norms. ${ }^{291}$ Consequently, given that as many as six million Americans have an LGBTQI parent ${ }^{292}$ and that conservatively two million American children are being currently raised by at least one LGBTQI parent, ${ }^{293}$ the curricular "no promo homo" laws certainly do not achieve the purposes of education as articulated in Brown.

Instead, these curricular laws intentionally target and harm a discrete class of children who do not have control over the sexual choices of their parents by allocating these children outsider or second-tier status. The peripheral effects of these curricular dictates are significant, ranging from blocked access to any type of positive educational treatment of LGBTQI individuals ${ }^{294}$ to crosspurposes of the antibullying and antiharassment efforts that many public schools are adopting. ${ }^{295}$ Further, the discriminatory, disparate treatment of LGBTQI families in these state laws constricts teacher and student speech that might run contrary to the states' conformity norms. ${ }^{296}$ Finally, these laws carry collateral damage in the form of imposing an "affront to one of the goals of the Equal Protection Clause: the abolition of governmental barriers presenting unreasonable obstacles to advancement on the basis of individual merit."297

These harms, including the constitutional Equal Protection violations of students with LGBTQI parents that result from the state legislation that stigmatizes or prohibits the teaching of nonheterosexual relationships in public schools, necessitate action now. Other avenues of recourse, aside from student-centered federal constitutional challenges, will not sufficiently remediate these injuries. By striving to finally and completely invalidate these

${ }^{290}$ Brown v. Bd. of Educ., 347 U.S. 483, 493 (1954).

291 See supra text accompanying notes $155-57$.

292 See Gary J. Gates, The Williams Inst., UCLA SCH. OF LAW, LGBT PARENTING IN THE UNITED STATES 1 (Feb. 2013), http://williamsinstitute.law.ucla.edu/wp-content/ uploads/LGBT-Parenting.pdf [http://perma.cc/RBY6-THEC] (providing the results of a demographic study of the LGBT population in the United States).

293 See Movement Advancement Project et Al., All Children Matter: How LEgal AND SOCIAL INEQUALities Hurt LGBT FAMiLies 7 (Oct. 2011), http://www.lgbtmap.org/file/all-children-matter-full-report.pdf [http://perma.cc/AK52-KYNU] (noting that while "[e]xact estimates of how many children are being raised by LGBT parents are difficult to obtain ... analysis of three different data sources suggests a range of 2.0 to 2.8 million children").

294 See, e.g., Chris Hampton, Am. Civil Liberties Union, "Don't Filter Me" INTERIM REPORT (Sept. 2011), https://www.aclu.org/files/assets/dontfilterme_report.pdf [http://perma.cc/WE9P-2SF6] (discussing widespread public school web filtering of any type of internet site that portrays LGBTQI relationships in any positive light).

295 See supra text accompanying notes 213-15.

296 See, e.g., supra text accompanying notes 102-03.

297 Plyler v. Doe, 457 U.S. 202, 221-22 (1982). 
laws, student children of LGBTQI families can achieve inclusive, constitutional equality in areas of supreme importance to American jurisprudence and civic democracy: both education and the family. ${ }^{298}$ This type of "inclusion strengthens, rather than weakens, [these] most important institutions." 299 Finally, this type of recognition, like the Supreme Court's recognition of the fundamental Fourteenth Amendment right to marry that is afforded to same-sex couples, will "provide[] powerful confirmation from the law itself that" all individuals "can create loving, supportive families" regardless of sexual orientation or gender identity. 300

298 See Smith v. Org. of Foster Families for Equal. \& Reform, 431 U.S. 816, 844 (1977) ("[T]he importance of the familial relationship, to the individuals involved and to the society, stems from the emotional attachments that derive from the intimacy of daily association, and from the role it plays in 'promot[ing] a way of life' through the instruction of children." (second alteration in original) (citing Wisconsin v. Yoder, 406 U.S. 205, 231$33(1972)))$.

${ }^{299}$ Latta v. Otter, 771 F.3d 456, 476 (9th Cir. 2014).

300 Obergefell v. Hodges, 135 S. Ct. 2584, 2600 (2015). 